\title{
BNREL
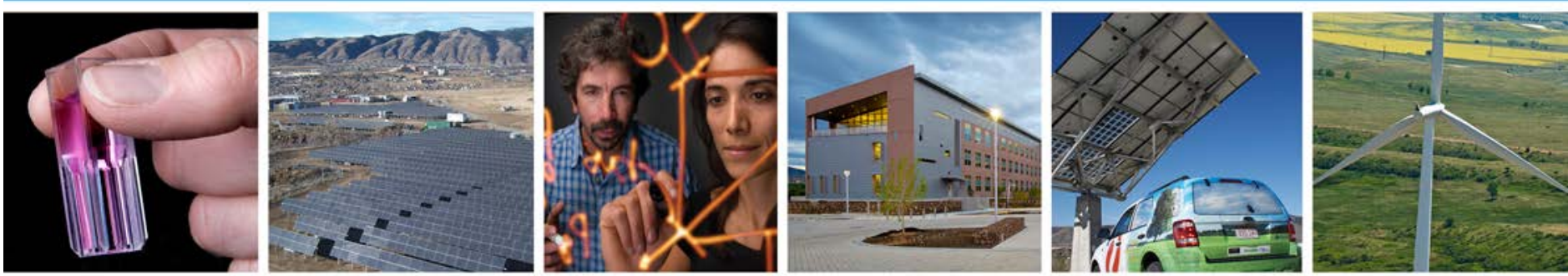

\section{Sensitivity of Rooftop PV Projections in the SunShot Vision Study to Market Assumptions}

Easan Drury, Paul Denholm, and Robert Margolis 


\section{Sensitivity of Rooftop PV Projections in the SunShot Vision Study to Market Assumptions}

Easan Drury, Paul Denholm, and Robert Margolis

Prepared under Task No. SS12.2220

NREL is a national laboratory of the U.S. Department of Energy, Office of Energy Efficiency \& Renewable Energy, operated by the Alliance for Sustainable Energy, LLC.

National Renewable Energy Laboratory 15013 Denver West Parkway Golden, Colorado 80401 303-275-3000 • www.nrel.gov
Technical Report

NREL/TP-6A20-54620

January 2013

Contract No. DE-AC36-08GO28308 


\section{NOTICE}

This report was prepared as an account of work sponsored by an agency of the United States government. Neither the United States government nor any agency thereof, nor any of their employees, makes any warranty, express or implied, or assumes any legal liability or responsibility for the accuracy, completeness, or usefulness of any information, apparatus, product, or process disclosed, or represents that its use would not infringe privately owned rights. Reference herein to any specific commercial product, process, or service by trade name, trademark, manufacturer, or otherwise does not necessarily constitute or imply its endorsement, recommendation, or favoring by the United States government or any agency thereof. The views and opinions of authors expressed herein do not necessarily state or reflect those of the United States government or any agency thereof.

Available electronically at http://www.osti.gov/bridge

Available for a processing fee to U.S. Department of Energy and its contractors, in paper, from:

U.S. Department of Energy

Office of Scientific and Technical Information

P.O. Box 62

Oak Ridge, TN 37831-0062

phone: 865.576 .8401

fax: 865.576 .5728

email: mailto:reports@adonis.osti.gov

Available for sale to the public, in paper, from:

U.S. Department of Commerce

National Technical Information Service

5285 Port Royal Road

Springfield, VA 22161

phone: 800.553 .6847

fax: 703.605.6900

email: orders@ntis.fedworld.gov

online ordering: http://www.ntis.gov/help/ordermethods.aspx

Cover Photos: (left to right) PIX 16416, PIX 17423, PIX 16560, PIX 17613, PIX 17436, PIX 17721

Printed on paper containing at least $50 \%$ wastepaper, including $10 \%$ post consumer waste. 


\section{Acknowledgments}

We thank Albert Chan at the Rocky Mountain Institute, and Trieu Mai, Robin Newmark, and Sean Ong at the National Renewable Energy Laboratory for comments and input. This work was supported by the U.S. Department of Energy under contract number DE-AC36-08GO28308. 


\section{Executive Summary}

The U.S. Department of Energy's (DOE) SunShot Vision Study (DOE 2012) explored the impact of reducing solar prices by about $75 \%$ from 2010 to 2020 on the potential deployment of solar technologies in the United States. DOE's SunShot Initiative envisions reaching a \$1.50/W installed system price for residential rooftop photovoltaic (PV) systems by 2020 and a $\$ 1.25 / \mathrm{W}$ installed price for commercial rooftop PV systems by 2020. The SolarDS model was used to simulate rooftop PV market demand based on these price projections, ${ }^{1}$ along with several market assumptions, including customer access to financing, future retail electricity rates, and netmetering policies. In the SunShot Vision Study, U.S. rooftop PV demand increased from about $1 \mathrm{GW}$ in 2010 to $121 \mathrm{GW}$ by 2030 and $240 \mathrm{GW}$ by 2050 .

Rooftop PV demand is sensitive to several factors in addition to installed system prices. In this study we explore the sensitivity of simulated PV demand to four key model assumptions:

1. PV system financing by varying customer down payment fractions from $0 \%$ to $100 \%$

2. Valuation of $\mathbf{P V}$-generated electricity ranging from retail electricity rates to the variable cost of natural gas generation

3. Future retail electricity rates based on annual escalation rates ranging from $0 \% / \mathrm{yr}$ to $1 \% / y r$ (real dollars)

4. Modeled representations of customer adoption behavior based on different parameterizations of aggregate customer behavior from previous studies.

We find that simulated U.S. rooftop PV demand is highly sensitive to these factors - particularly PV financing assumptions - which can impact modeled PV deployment by up to $\pm 70 \%$.

However, we find that robust rooftop PV markets develop in all scenarios if the SunShot price targets are reached, with the lowest levels of PV demand reaching $38 \mathrm{GW}$ by 2030 and $74 \mathrm{GW}$ by 2050. This represents significant market growth, up from about $3.9 \mathrm{GW}$ of U.S. rooftop PV capacity installed by the end of the third quarter in 2012 (SEIA-GTM 2012).

We also explore the impact of varying rooftop PV prices in conjunction with other market assumptions. We find that the relative impact of each market parameter (fractional increase or decrease in demand) is similar for PV prices ranging from $\$ 1 / \mathrm{W}$ to $\$ 4 / \mathrm{W}$, but that the absolute impact (GW of demand) increases significantly at lower prices. Modeled PV demand could reach the reference SunShot deployment levels $(121 \mathrm{GW}$ by $2030 ; 240 \mathrm{GW}$ by 2050) at prices up to $\$ 1 / \mathrm{W}$ higher than the SunShot Initiative price targets if customers gain access to innovative financing with no up-front costs; or PV systems may need to reach far lower price targets than those envisioned in the SunShot Initiative to stimulate similar demand if current electricity rates structures are modified. This analysis demonstrates the extent to which PV demand is driven by several factors in addition to installed system prices and highlights opportunities for emerging business models and federal, state, and local policies to impact PV demand.

\footnotetext{
${ }^{1} \mathrm{PV}$ prices were assumed to linearly decline from current costs to the SunShot price targets by 2020 and remain at the SunShot targets through 2050.
} 


\section{Table of Contents}

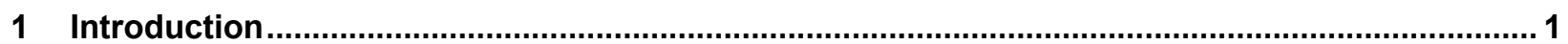

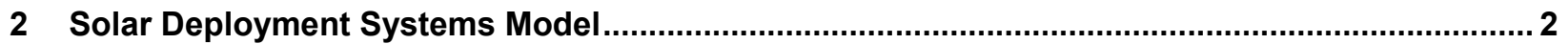

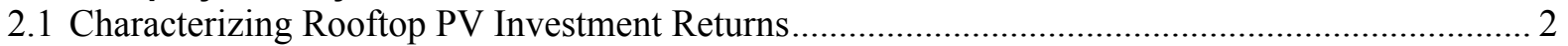

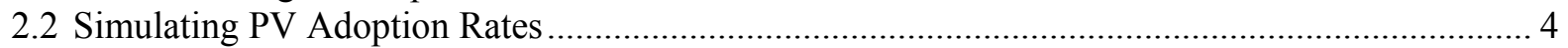

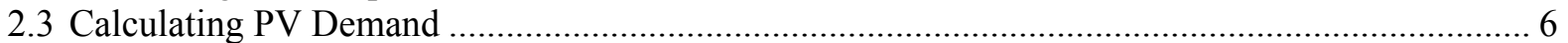

3 Rooftop PV Demand in the SunShot Vision Study ................................................................. 7

4 Sensitivity of Rooftop PV Penetration to Varying Market Parameters........................................ 13

5 Sensitivity of Rooftop Markets to PV Prices and Non-Price Parameters .................................... 18

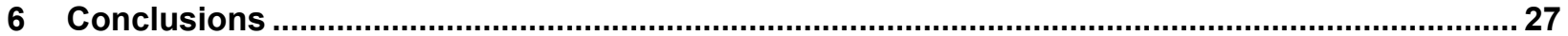

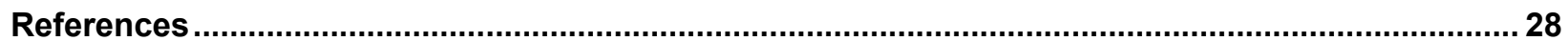




\section{List of Figures}

Figure 1. Solar resource regions used in SolarDS, based on the 216 TMY3 stations shown by triangles

Figure 2. Retail electricity rates from over 1,000 utilities (EIA 2007) are used to characterize state-based electricity rate distributions.

Figure 3. Relationships between PV economic returns and market potential from previous studies

Figure 4. Modeled PV diffusion parameters based on the Bass diffusion model............................6

Figure 5. Rooftop PV penetration in the DOE SunShot initiative study ..................................10

Figure 6. Cumulative rooftop PV capacity for the SunShot scenario........................................11

Figure 7. Modeled rooftop PV demand for the SunShot PV price assumptions (Table 1) and a range of non-price market parameters (Table 4).............................................................15

Figure 8. SunShot PV price assumptions for residential and commercial systems and the price sensitivities explored for residential systems. Similar price sensitivities are used for commercial systems with a \$5/W starting price in 2010 and identical 2020-2050 prices......18

Figure 9. Sensitivity of rooftop PV demand to a range of PV prices for 2030 and $2050 \ldots \ldots \ldots \ldots . . .19$

Figure 10. Rooftop PV demand for a range of PV prices and other market assumptions in 2030

Figure 11. Rooftop PV demand for a range of PV prices and other market assumptions in 2050 .......

Figure 12. Simulated rooftop PV market demand for SunShot price targets reached in 2030 rather than 2020

\section{List of Tables}

Table 1. Residential and Commercial PV Price Projections Used in the SunShot Vision Study .....7

Table 2. Key Market Assumptions Used to Model Rooftop PV Demand in the SunShot Vision Study.....

Table 3. Financing Assumptions Used in the SunShot Vision Study

Table 4. Parameters Explored in the Sensitivity Analysis

Table 5. Rooftop PV Capacity $\left(\mathrm{GW}_{\mathrm{DC}}\right)$ for a Range of Non-Price Market Parameters....

Table 6. Modeled 2030 Rooftop PV Demand $\left(\mathrm{GW}_{\mathrm{DC}}\right)$ for Several Installed PV System Prices and a Range of Market Assumptions

Table 7. Modeled 2050 Rooftop PV Demand $\left(\mathrm{GW}_{\mathrm{DC}}\right)$ for Several Installed PV System Prices and a Range of Market Assumptions

Table 8. Range in PV Prices (2010 USD/W $\mathrm{WC}_{\text {DC }}$ ) Enabling SunShot Levels of Rooftop PV Market Demand 


\section{Introduction}

The SunShot Initiative was launched by the U.S. Department of Energy (DOE) in 2011 to reduce the cost of solar electricity by approximately $75 \%$ from 2010 to 2020 , whereby solar energy could compete with conventional electricity sources without subsidies. DOE conducted the SunShot Vision Study (DOE 2012) to evaluate the potential impacts of achieving these price and performance improvements. The underlying modeling analysis suggested that reaching the SunShot price targets would enable unsubsidized solar energy to satisfy roughly $14 \%$ of U.S. electricity demand by 2030 and $27 \%$ by $2050 .{ }^{2}$ Simulated residential and commercial rooftop markets contributed $121 \mathrm{GW}$ by 2030 (3.5\% of U.S. electricity demand) and $240 \mathrm{GW}$ by 2050 (5.9\% of U.S. demand).

Rooftop photovoltaic (PV) markets are driven by PV prices and several non-price market factors, like financing terms and retail electricity rates (Drury et al. 2010). The Solar Deployment System (SolarDS) model (Denholm et al. 2009) was developed by the National Renewable Energy Laboratory (NREL) to explore the impact of these, and other, variables on residential and commercial rooftop PV demand in the United States.

SolarDS was used to simulate residential and commercial rooftop PV markets in the SunShot Vision Study (DOE 2012). Rooftop PV prices were assumed to reach the SunShot price targets by 2020 , which is $\$ 1.50 / \mathrm{W}$ for residential systems and $\$ 1.25 / \mathrm{W}$ for commercial systems, ${ }^{3}$ and PV prices were assumed to stay fixed at SunShot prices through 2050. In addition to PV price projections, several non-price market parameters were assumed to simulate PV demand, including system financing characteristics, retail electricity rates and rate escalations, the value of distributed PV electricity (including net-metering policy), and customer adoption characteristics. Market parameters were chosen to represent current market conditions; however, different assumptions could significantly increase or decrease modeled rooftop PV demand.

In this study, we explore the sensitivity of simulated rooftop PV markets to several non-price market assumptions for both the SunShot Initiative PV price targets and a range of PV prices. These sensitivities highlight key model parameters that drive simulated solar demand and how the sensitivity to each market assumption can vary with PV price. From a modeling perspective, these sensitivities help characterize the robustness of future market projections within the context of several unknowable market factors. From a policy perspective, these sensitivities can help identify key market variables that could significantly impact PV demand in addition to system prices.

This report is organized as follows: Section 2 provides a brief overview of the SolarDS model; Section 3 summarizes the key modeling assumptions used in the SunShot Vision Study; Section 4 explores the sensitivity of PV deployment to a range of market assumptions at SunShot prices; Section 5 explores the impact of varying both PV prices and several market factors; and Section 6 summarizes study conclusions.

\footnotetext{
${ }^{2}$ All results represent the contiguous United States, excluding Alaska and Hawaii.

${ }^{3}$ Here and elsewhere, all PV costs are given in units of 2010 U.S. dollars (2010 USD) per unit of direct current (DC) nameplate capacity, unless specified otherwise.
} 


\section{Solar Deployment Systems Model}

SolarDS is a market-penetration model that simulates residential and commercial rooftop PV markets in the contiguous United States through 2050 (Denholm et al. 2009). SolarDS was developed to examine the possible evolution of rooftop PV markets based on several factors, including installed PV system prices, regional solar resources and electricity rates, financing structures, electricity rate escalations and rate structures, net metering, carbon policy, and federal and local incentives.

The SolarDS model simulates rooftop PV markets in three primary steps:

1. Characterizing rooftop PV investment returns using a combination of PV prices, regional solar resources, local electricity rates, financing structures, net-metering policy, incentives, and other market characteristics

2. Simulating PV adoption rates for residential and commercial customers based on PV economic returns using parameterizations of aggregate customer behavior

3. Calculating PV demand based on a combination of regional PV adoption rates with local customer characteristics and residential and commercial building stock projections.

Each component of the SolarDS model is described briefly here and in detail in Denholm et al. (2009).

\subsection{Characterizing Rooftop PV Investment Returns}

The value of a PV investment is based on installed system prices and regionally varying PV revenues. Potential PV revenues are estimated based on the combination of regional PV performance and retail electricity rates and rate structures. SolarDS simulates 'typical' hourly PV output in 216 model regions (Figure 1) using Typical Meteorological Year (TMY3) stations from the National Solar Radiation Database (NREL 2007). PV output is calculated for several roof orientations, including flat-mounted modules and modules tilted at $25^{\circ}$ (representative of a common roof tilt) with azimuth orientations ranging from $\pm 90^{\circ}$ from south in $30^{\circ}$ increments. Alternating current (AC) PV output is calculated for each location and orientation using the PVFORM/PVWATTS model (Marion et al. 2005).

PV performance is associated with groups of census blocks, which are used to generate the 216 solar resource regions shown in Figure 1. 


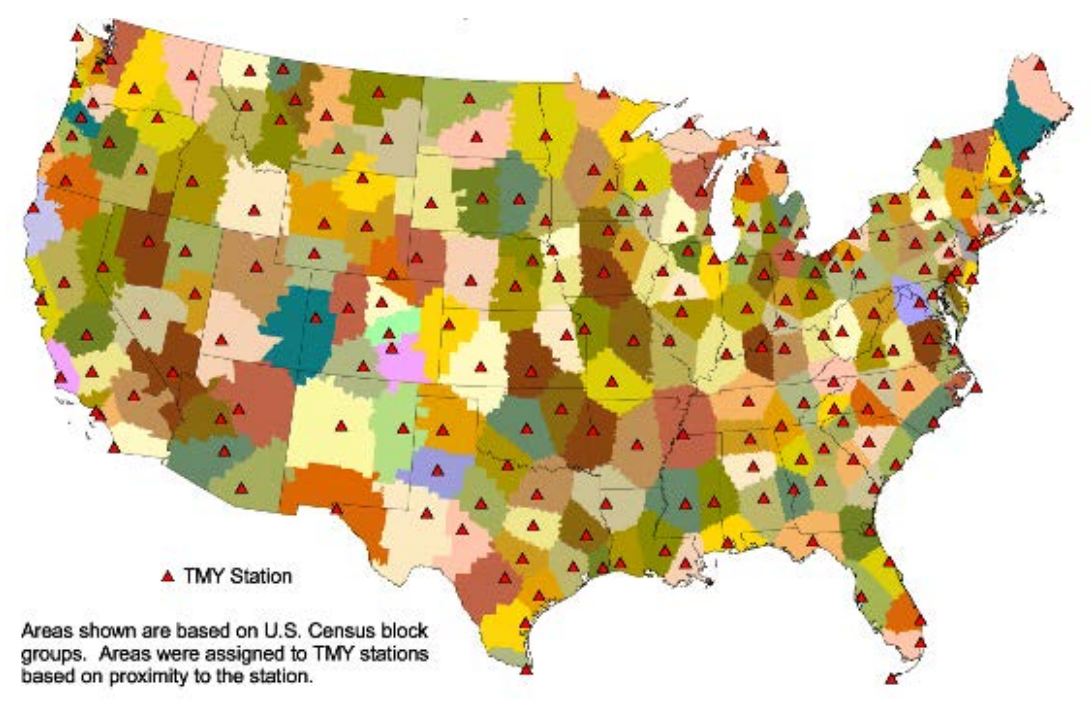

Figure 1. Solar resource regions used in SolarDS, based on the 216 TMY3 stations shown by triangles

Local retail electricity rates and rate structures vary significantly both within and between states. Retail electricity rate distributions are characterized for each state using Energy Information Administration (EIA) form 861 data (EIA 2007), which provides total revenue and sales for over 3,000 electric service providers in the United States. Regional electricity rate structures (flat, time-of-use, and demand-based rates) are characterized using tariff sheets from the largest service providers in each state. Electricity rate escalations are projected through 2035 using EIA's Annual Energy Outlook (AEO) 2010 data (EIA 2010a) and extrapolated from 2035 to 2050 using the mean AEO growth rates from 2025-2035.

Figure 2 illustrates the distribution of residential retail electricity rates for five U.S. states. A PV investment is much more attractive for the fraction of customers paying the highest rates, and SolarDS simulates increased PV adoption in these regions. 


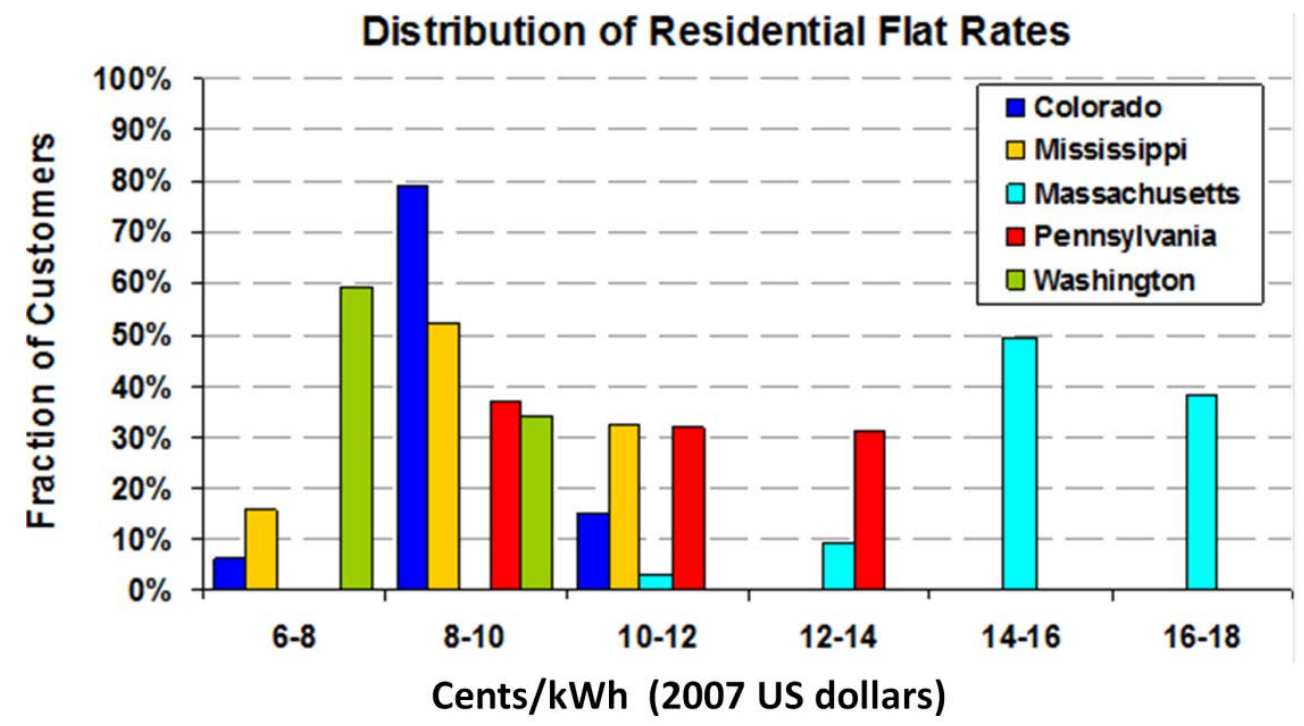

Figure 2. Retail electricity rates from over 1,000 utilities (EIA 2007) are used to characterize statebased electricity rate distributions

Future net-metering policies must also be assumed to calculate PV revenues. PV electricity is frequently valued at retail electricity rates in several U.S. markets; however, this could change in the future as PV markets grow (VSI/NNEC 2011). This change could take several forms. For example, during times when PV generation is less than customer demand, PV may offset retail electricity rates to a customer by reducing net electricity demand; during times when PV generation exceeds demand and electricity is exported to the grid, the value of surplus PV electricity could range from zero to wholesale electricity rates to retail rates. Retail electricity rates could also be restructured to separate the fixed cost of providing electricity services (e.g., generation assets or transmission and distribution assets) from the variable cost of generating electricity (e.g., fuel costs and operations and maintenance costs). Future electricity rates and rate structures are inherently unknowable, and we use the SolarDS model to explore the sensitivity of rooftop PV demand to a range of methods for valuing PV electricity.

\subsection{Simulating PV Adoption Rates}

Modeled PV system prices and revenues are combined into one economic performance metric that is used to project PV adoption. SolarDS uses payback time to simulate how residential and commercial customers frequently value a potential energy efficiency or PV investment (Kastovich et al. 1982; EIA 2004; EIA 2010b; Paidipati et al. 2008; R.W. Beck, Inc. 2009; Rai and Sigrin 2012). We use two payback metrics to represent customer decision making processes - a "time-to-net-positive cash flow" payback time for residential customers ${ }^{4}$ and an internal rate of return (IRR)-based payback time for commercial customers (Denholm et al. 2009; EIA 2010b). Different economic performance metrics were used for residential and commercial customers to reflect their different investment priorities and adoption criteria (EIA 2010b).

\footnotetext{
${ }^{4}$ The time-to-net-positive cash flow metric represents the time required for the revenue generated by a PV investment to exceed the cost of the system to date and for net cash flows to remain positive for the duration of the investment. This metric is similar to the discounted payback time metric (e.g., Audenaert et al. 2010) that is frequently used for European projects.
} 
Aggregate PV adoption rates are simulated using relationships between PV payback times and maximum PV adoption fractions and a market diffusion rate that characterizes how quickly the maximum PV market potential is realized. We characterize the maximum customer adoption fraction, or market share, based on previous survey studies and expert elicitations from PV market participants (Kastovich et al. 1982; EIA 2004; Paidipati et al. 2008; R.W. Beck, Inc. 2009). Figure 3 shows the maximum market share relationships that are used in the SolarDS model.

PV Maximum Market Share

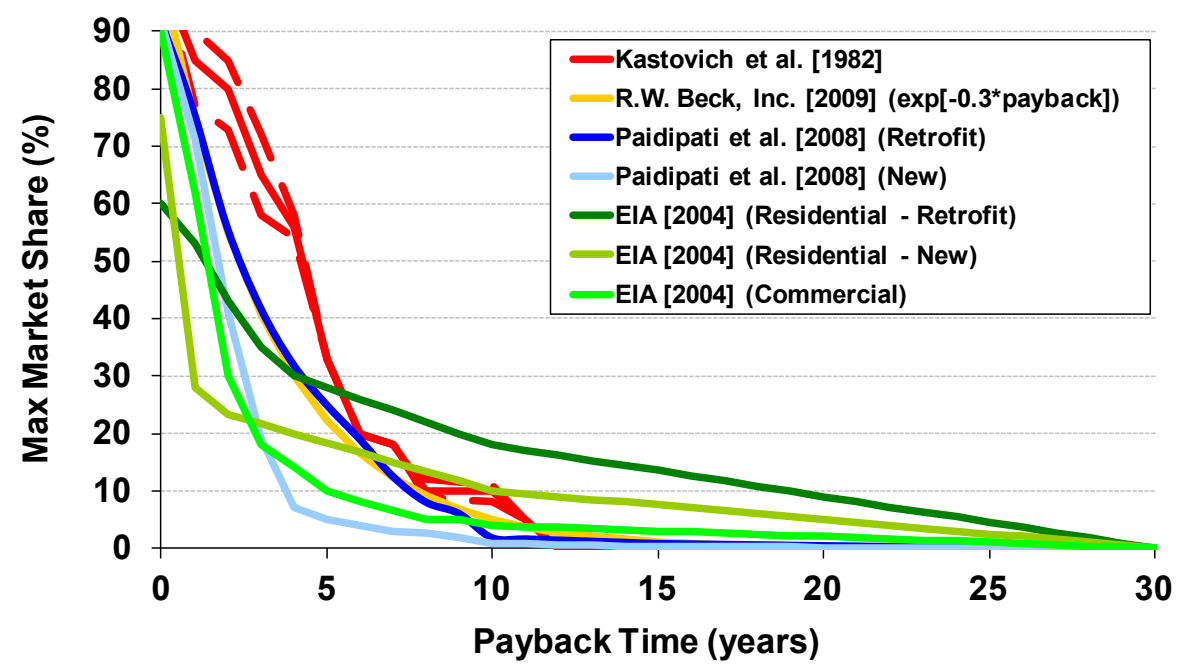

Figure 3. Relationships between PV economic returns and market potential from previous studies

The rate at which durable goods gain market share, or diffuse into a potential market, has been actively researched for several decades. SolarDS characterizes PV diffusion rates using a modified Bass diffusion model (Bass 1969; Denholm et al. 2009). The Bass model simulates aggregate adoption that is driven by the influence of both early adopters (using a coefficient of innovation) and late adopters (using a coefficient of imitation).

Figure 4 shows a sample Bass diffusion relationship (coefficient of innovation: $p=0.0015$, coefficient of imitation: $q=0.4$ ). Using these parameters, annual diffusion rates peak at 18 years after the product enters the market, and the product has almost completely diffused to its full potential after 30 years. This diffusion relationship is used for PV systems in SolarDS when PV payback times are between 3 and 10 years. PV diffusion rates are modified based on PV economics, with more rapid diffusion rates for payback times less than 3 years and less rapid diffusion rates for payback times greater than 10 years (Denholm et al. 2009). Diffusion rates are also modified as maximum market sizes change for each region based on changing PV prices, retail electricity rates and rate structures, expiring incentives, and other factors as described in Denholm et al. (2009). In general, we find that diffusion model structure and parameters can significantly impact short-term adoption rates $(<20$ years) but become less important for longerterm simulations ( $>20$ years) when market diffusion begins to saturate. 


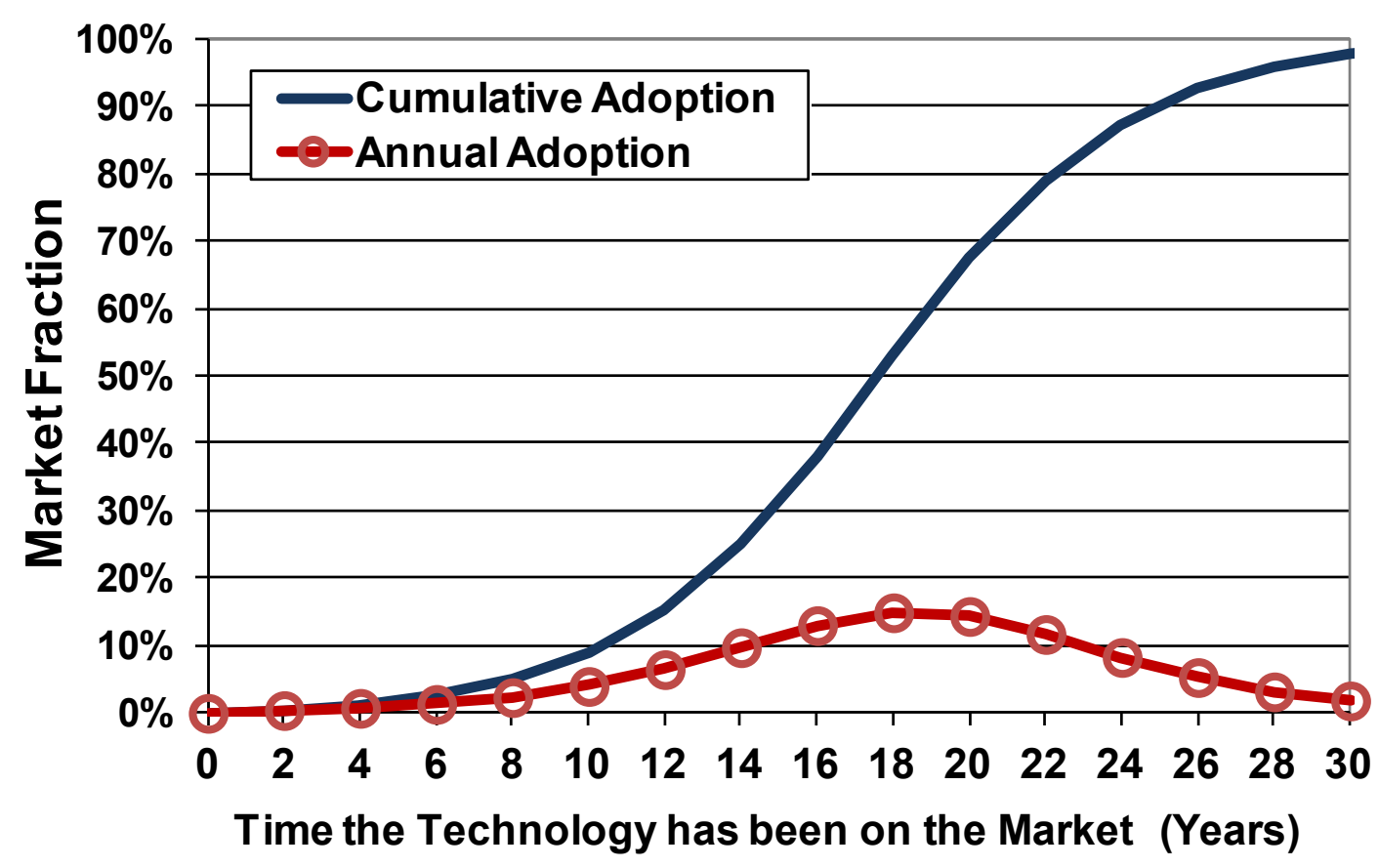

Figure 4. Modeled PV diffusion parameters based on the Bass diffusion model (Bass 1969)

\subsection{Calculating PV Demand}

The final step in simulating rooftop PV demand is relating customer adoption rates to residential and commercial capacity additions. This is done using a building stock database that includes 4 types of residential buildings and 14 types of commercial buildings. The building stock database was statistically filtered to remove shaded roofs, obstructed roof space, and roofs that are unsuitable for PV adoption ${ }^{5}$ (Paidipati et al. 2008; Denholm and Margolis 2008; Denholm et al. 2009). Market adoption fractions are calculated for each building type and installation type (building retrofit and re-roof/new construction), and these are combined with building-specific PV system size distributions (residential systems are assumed to have mean sizes of about $5 \mathrm{~kW}$, and commercial systems typically have mean sizes ranging from $75-100 \mathrm{~kW}$, depending on the deployment scenario). Using this methodology, we estimate that the technical potential for residential and commercial rooftop PV markets is approximately $300 \mathrm{GW}$ each (Denholm et al. 2009). Economic potentials are sensitive to several market parameters, as explored in the following sections.

\footnotetext{
${ }^{5}$ Approximately $40 \%-65 \%$ of residential buildings, and a similar fraction of commercial roof space, are estimated to be suitable for PV installations, based on building types and locations (e.g., Denholm et al. 2009).
} 


\section{Rooftop PV Demand in the SunShot Vision Study}

Several market assumptions were used to simulate the evolution of solar markets in the SunShot Vision Study. This section describes key assumptions and the simulated rooftop PV market demand.

The SunShot Vision Study explored the potential growth of rooftop PV markets if installed residential system prices reach $\$ 1.50 / \mathrm{W}$ by 2020 (2010 U.S. dollars) and installed commercial prices reach $\$ 1.25 / \mathrm{W}$ (DOE 2012). Table 1 summarizes PV price projections used in the study. The 2010 PV prices are based on host-owned PV systems that were bid in 2010 and installed in 2010 and 2011 (BNEF 2012). Recent PV price characterizations bound these 2010 prices, with lower estimates from bottom-up cost modeling (Goodrich et al. 2012) and higher estimates from historical market prices that include both host-owned and third-party-owned PV systems ${ }^{6}$ (Barbose et al. 2011). PV prices were assumed to decrease linearly from 2010 market prices to 2020 SunShot goals. PV prices were assumed to remain at the SunShot targets from 2020 through 2050 (DOE 2012).

Table 1. Residential and Commercial PV Price Projections Used in the SunShot Vision Study

\begin{tabular}{|ccc|}
\hline Year & $\begin{array}{c}\text { Residential } \\
(\mathbf{2 0 1 0} \\
\left.\text { USD/W }_{\text {DC }}\right)\end{array}$ & $\begin{array}{c}\text { Commercial } \\
\mathbf{( 2 0 1 0} \\
\left.\text { USD/W }_{\text {DC }}\right)\end{array}$ \\
\hline $\mathbf{2 0 1 0}$ & 6.00 & 5.00 \\
$\mathbf{2 0 2 0}$ & 1.50 & 1.25 \\
$\mathbf{2 0 3 0}$ & 1.50 & 1.25 \\
$\mathbf{2 0 4 0}$ & 1.50 & 1.25 \\
$\mathbf{2 0 5 0}$ & 1.50 & 1.25 \\
\hline
\end{tabular}

In addition to installed system prices, several PV market assumptions were used to simulate PV demand in the Sunshot Vision Study. Key market parameters are summarized in Table 2, and financing assumptions are described in Table 3. Each market assumption was chosen to represent current (and possible future) PV market dynamics. Several market factors, like future electricity rates, rate structures, net-metering policy, and dynamic customer behavior, are inherently unknowable and represent both market and model uncertainty.

\footnotetext{
${ }^{6}$ Third-party PV companies often use a fair market value (FMV) approach to report project prices, and these can be higher than the cost-based prices reported for host-owned systems (Barbose et al. 2011; Goodrich et al. 2012; BNEF 2012). Including third-party-owned systems with host-owned systems can inflate aggregate price statistics above project costs.
} 
Table 2. Key Market Assumptions Used to Model Rooftop PV Demand in the SunShot Vision Study

\begin{tabular}{|c|c|}
\hline \multicolumn{2}{|r|}{ Key Market Assumptions Explored in This Analysis } \\
\hline $\begin{array}{l}\text { PV Financing } \\
\text { Assumptions }\end{array}$ & See Table 3 \\
\hline $\begin{array}{l}\text { PV Electricity } \\
\text { Valuation }\end{array}$ & $\begin{array}{l}\text { The value of PV electricity is impacted by several factors like net-metering policy and } \\
\text { electricity rate structures. In the SunShot Vision Study, we assumed that residential PV } \\
\text { electricity is valued based on a mix of flat and time-of-use rates and that } 90 \% \text { of PV } \\
\text { electricity is valued at retail rates, and } 10 \% \text { is valued at the variable cost of natural gas } \\
\text { generation. }{ }^{\text {a }} \text { For commercial systems, we assumed a mix of flat and demand-based } \\
\text { rates and that } 100 \% \text { of commercial PV electricity is valued at retail electricity rates. }\end{array}$ \\
\hline $\begin{array}{l}\text { Retail Rate } \\
\text { Escalations }\end{array}$ & 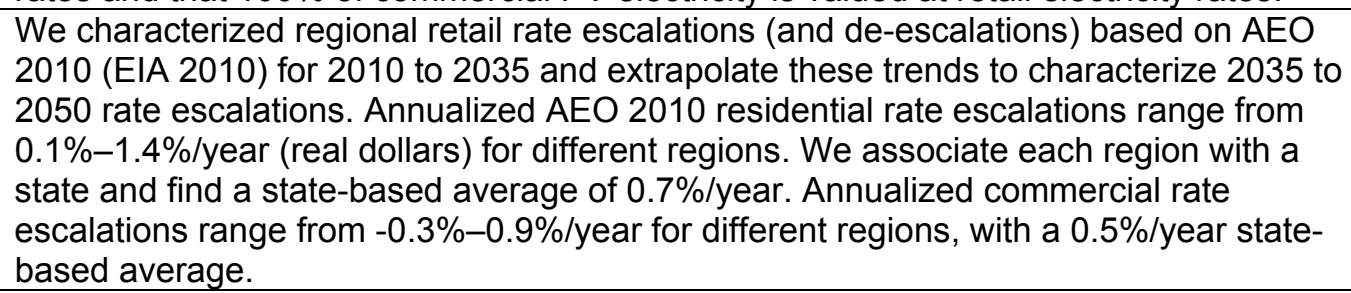 \\
\hline $\begin{array}{l}\text { Parameterizing } \\
\text { Customer Behavior }\end{array}$ & $\begin{array}{l}\text { We characterized customer adoption using two steps: (1) We estimate the total PV } \\
\text { market share (fraction of the population that may adopt rooftop PV at some point) } \\
\text { based on PV payback times using the relationship from Paidipati et al. (2008); and (2) } \\
\text { we simulate the diffusion of rooftop PV into this maximum market potential over time } \\
\text { using a modified Bass diffusion model (see Denholm et al. 2009). }\end{array}$ \\
\hline \multicolumn{2}{|r|}{ Additional Market Assumptions } \\
\hline $\begin{array}{l}\text { Retail Electricity } \\
\text { Rates }\end{array}$ & $\begin{array}{l}\text { We characterized a distribution of retail electricity rates for each state using EIA form } \\
861 \text { data (EIA 2007). }\end{array}$ \\
\hline Incentives & $\begin{array}{l}\text { We included current state and federal PV incentives (DSIRE 2012) and assumed that } \\
\text { the federal investment tax credit (ITC) will expire at the end of } 2016 \text { for both residential } \\
\text { and commercial systems. }{ }^{c} \text { We assume that the Modified Accelerated Cost Recovery } \\
\text { System (MACRS) capital depreciation schedule will remain in place through } 2050 \text {. }\end{array}$ \\
\hline Carbon Price & $\begin{array}{l}\text { We assumed that carbon emissions would not be priced, or otherwise limited, for the } \\
\text { duration of the SunShot Vision Study through } 2050 \text {. }\end{array}$ \\
\hline $\begin{array}{c}\text { PV Interconnection } \\
\text { and Integration } \\
\text { Costs }\end{array}$ & $\begin{array}{l}\text { We assumed that PV interconnection costs were included in the SunShot price targets. } \\
\text { We did not include potential rooftop PV integration costs or benefits on distribution } \\
\text { networks, but we did capture the impact of distributed and wholesale PV generation on } \\
\text { the optimal deployment of utility-scale solar and other generation resources in } \\
\text { wholesale markets in the SunShot Vision Study (DOE 2012; Eurek et al. 2013). }\end{array}$ \\
\hline $\begin{array}{l}\text { Building Stock } \\
\text { Projections }\end{array}$ & $\begin{array}{l}\text { Regional residential and commercial building characteristics were developed based on } \\
\text { EIA's residential and commercial energy consumption surveys (EIA 2008a; EIA } \\
\text { 2008b). Building stocks were assumed to increase over time based on projected } \\
\text { population growth (see Denholm et al. 2009). }\end{array}$ \\
\hline
\end{tabular}

${ }^{a}$ The value of offsetting natural gas generation is dependent on several factors, including regional natural gas prices, aggregate natural gas heat rates (based on the time- and region-dependent mix of combined cycle and combustion turbine generation), operations and maintenance costs, transmission congestion, and other factors. We estimate the average cost of natural gas generation for each state based on historical fuel and electricity prices from EIA (2009) along with natural gas combined cycle and combustion turbine characteristics from Black \&Veatch (2012) and use these to scale the regional rate distributions calculated from (EIA 2007). This results in variable natural gas prices ranging from $\$ 35-\$ 75 / \mathrm{MWh}$, based on regional natural gas prices, and a state-based mean of $\$ 61 / \mathrm{MWh}$. We do not project future natural gas prices because these are inherently uncertain; instead we assume that the variable value of offsetting natural gas generation remains fixed through the duration of the study in real dollars.

${ }^{\mathrm{b}}$ Both residential and commercial customers could reduce the size of PV installations to increase the fraction of PV generation that offsets on-site demand and decrease the amount of electricity exported to the grid (Darghouth et al. 2010).

${ }^{\mathrm{c}}$ Current legislation stipulates that the $30 \%$ federal ITC will expire for residential systems at the end of 2016 and reduce to $10 \%$ for commercial systems (DSIRE 2012). However, we conservatively assumed that the federal ITC will expire for both residential and commercial PV systems at the end of 2016. 
Table 3. Financing Assumptions Used in the SunShot Vision Study

\begin{tabular}{|c|c|c|c|}
\hline & \multicolumn{2}{|c|}{ Residential } & \multirow{2}{*}{ Commercial } \\
\hline & New & Retrofit & \\
\hline Inflation Rate ${ }^{a}$ & $3 \%$ & $3 \%$ & $3 \%$ \\
\hline Loan Rate (real) & $4.5 \%^{b}$ & $6 \%^{c}$ & $4.5 \%^{d}$ \\
\hline Loan Term (years) & 30 & 15 & 20 \\
\hline Debt Fraction & $\begin{array}{l}80 \%- \\
100 \%{ }^{e}\end{array}$ & $\begin{array}{l}80 \%- \\
100 \%{ }^{e}\end{array}$ & $60 \%$ \\
\hline Equity Rate (real) & $N / A^{\dagger}$ & $N / A^{\dagger}$ & $N / A^{g}$ \\
\hline $\begin{array}{l}\text { Down Payment (equity } \\
\text { fraction) }\end{array}$ & $0 \%-20 \%{ }^{\mathrm{e}}$ & $0 \%-20 \%{ }^{\mathrm{e}}$ & $40 \%$ \\
\hline Discount Rate (real) & $N / A^{h}$ & $N / A^{h}$ & $N / A^{i}$ \\
\hline Depreciation & $\mathrm{N} / \mathrm{A}$ & N/A & MACRS \\
\hline Federal Tax & $\begin{array}{l}25 \%- \\
33 \%^{k}\end{array}$ & $\begin{array}{l}25 \%- \\
33 \%^{k}\end{array}$ & $35 \%$ \\
\hline State Tax & by state & by state & by state \\
\hline $\begin{array}{l}\text { PV/Concentrating Solar } \\
\text { Power Lifetime (years) }\end{array}$ & 30 & 30 & 30 \\
\hline
\end{tabular}

${ }^{a}$ Based on historical U.S. gross domestic product (GDP) deflator data over the last 30 years. Accessed November 2010: http://research.stlouisfed.org/fred2/data/GDPDEF.txt.

${ }^{\mathrm{b}}$ Based on a 20-year historical average of real U.S. 30-year fixed mortgage rates. Accessed January 20, 2010: www.freddiemac.com/pmms/pmms30.htm (Freddie Mac 2010).

${ }^{\mathrm{c}}$ Based on a 3-year historical average of real rates for $\$ 30,000$ U.S. home equity loans. Accessed January 20, 2010: www.wsjprimerate.us/home equity_loan_rates.htm.

${ }^{\mathrm{d}}$ Based on a 12-year historical average of real yields of corporate bonds rated Aa and A by Moody's (SIFMA 2010).

${ }^{\text {e }}$ Assumes that $80 \%$ of residential customers use a $20 \%$ down payment and $20 \%$ of residential customers use a $0 \%$ down payment to approximate alternate ownership structures such as third-party PV ownership (NREL 2009; SEIAGTM 2012) or property-assessed clean energy (PACE) style financing (NREL 2010).

${ }^{\mathrm{f}}$ Assumes that residential customers do not use an opportunity cost of capital to value cash while evaluating a PV investment.

${ }^{\mathrm{g}}$ Assumes that commercial customers use cash on hand, not equity investors, and do not use an opportunity cost of capital to value cash while evaluating a PV investment.

${ }^{\mathrm{h}}$ We use a simple, undiscounted payback time to represent PV investment returns for residential customers.

${ }^{\mathrm{i}}$ We use a payback time based on the PV IRR to represent PV investment returns for commercial customers. IRRs represent a discount rate where the net present value (NPV) of the PV system equals zero, and IRRs are calculated based on undiscounted future cash flows.

${ }^{\mathrm{j}}$ MACRS (modified accelerated cost recovery system) is applied to taxable commercial customers.

${ }^{\mathrm{k}}$ Assumes that $50 \%$ of residential customers are at a $28 \%$ federal tax rate and the other $50 \%$ are at a $33 \%$ federal tax rate.

Figure 5 shows the rooftop PV markets simulated by SolarDS for the SunShot Vision Study. Commercial PV markets are projected to grow more quickly, and to higher capacity, than residential markets. For example, commercial PV capacity reaches $15 \mathrm{GW}$ by 2020 (79\% of the rooftop market) and $80 \mathrm{GW}$ by 2030 (66\% of the rooftop market). However, commercial deployment rates begin to slow by 2030 as some of the top PV markets begin to saturate. At this point, residential markets begin to catch up, reaching $88 \mathrm{GW}$ by 2040 (44\% of the rooftop market) and $108 \mathrm{GW}$ by 2050 (45\% of the rooftop market). Modeled technical rooftop potential 
is about $300 \mathrm{GW}$ for both residential and commercial markets, and the SunShot scenario shows economic deployment on about $44 \%$ of suitable commercial roofs and $36 \%$ of suitable residential roofs by 2050 , representing about $20 \%$ of all residential and commercial buildings.

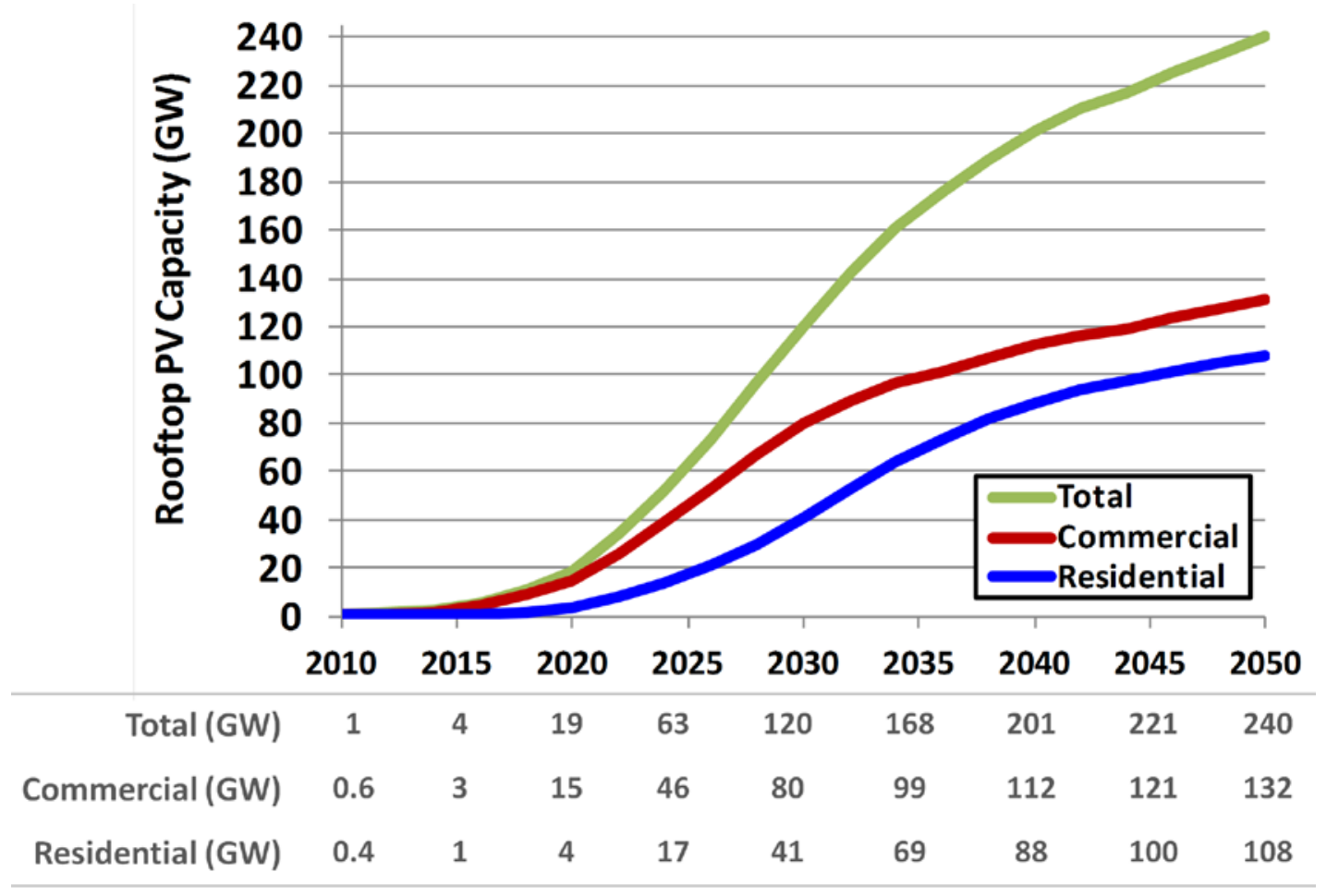

Figure 5. Rooftop PV penetration in the DOE SunShot initiative study

Note: Not all totals sum exactly due to rounding.

Simulated commercial PV markets grow more quickly than residential markets based on several factors, including: (1) commercial prices are lower per unit of PV capacity; (2) commercial PV is a depreciable asset ${ }^{7}$; and (3) the commercial IRR-based payback times used in SolarDS can be significantly shorter than residential payback times calculated using the time-to-net-positive cash flow metric ${ }^{8}$ (Drury et al. 2011). These factors drive robust commercial PV market growth before the SunShot price targets are fully reached in 2020, and meeting the SunShot price targets further increases growth rates. Residential PV markets begin to achieve robust growth after the SunShot prices are reached in 2020 and take longer to diffuse into their simulated market potential.

SolarDS does not characterize the impact of third-party-owned PV products on residential and commercial adoption decisions. These products are rapidly gaining market share in residential rooftop markets (SEIA-GTM 2012; Drury et al. 2012). As such, both the simulated rate of residential PV adoption and total amount of adoption may be underestimated in the SunShot scenario. We explore the sensitivity of rooftop PV deployment to different financing strategies in

\footnotetext{
${ }^{7}$ SolarDS does not characterize third-party-owned PV systems, which are depreciable assets.

${ }^{8}$ This is primarily caused by the assumption in calculating IRRs that positive PV cash flows can be reinvested at a rate of return equal to the system IRR. Revenue from the federal ITC and accelerated depreciation is implicitly assumed to be reinvested at very high rates for systems with high IRRs.
} 
Sections 4 and 5, in part to explore the potential impact of modifying some PV investment characteristics to resemble third-party PV products. However, this sensitivity does not fully capture how third-party products have modified PV investment characteristics (e.g., simplified adoption process or guaranteed PV performance) and customer adoption behavior, and this is an active area of research (Drury et al. 2011; Drury et al. 2012; Rai and Robinson 2012; Rai and Sigrin 2012) and model development.

Near-term PV market simulations (3 GW for commercial systems by 2015 and $1 \mathrm{GW}$ for residential systems by 2015) underestimate recent rooftop PV growth trends. Commercial rooftop markets reached about $2.6 \mathrm{GW}$ by the end of the third quarter (Q3) in 2012, growing at a rate of about $1 \mathrm{GW} / \mathrm{yr}$ (SEIA-GTM 2012). Residential rooftop markets reached about $1.2 \mathrm{GW}$ by the end of Q3 2012, growing at a rate of about $0.5 \mathrm{GW} / \mathrm{yr}$ (SEIA-GTM 2012). These growth trends could bring commercial rooftop PV markets to about $5 \mathrm{GW}$ by 2015 and residential markets to nearly $3 \mathrm{GW}$ by 2015 . However, PV incentives will decline or expire in several U.S. states before 2015 (DSIRE 2012), which will likely slow PV deployment in key markets like California. Incentive reduction and expiration schedules are represented in the SolarDS model, which limit near-term PV demand, particularly for residential systems. Near-term simulations may also underestimate recent trends because SolarDS does not characterize how third-partyowned PV systems have modified PV investment characteristics and customer adoption behavior. Lastly, near-term demand simulations are very sensitive to model diffusion parameters, which can lead to relatively high near-term model uncertainty.

Figure 6 shows regional rooftop PV demand for the SunShot scenario in 2030 and 2050. We find that key rooftop PV markets develop in California, Texas, and Florida, followed by Arizona and New York. Strong rooftop markets also develop in Colorado, Illinois, Pennsylvania, New Jersey, North Carolina, and Georgia. We find that market size, in units of installed capacity, is primarily driven by PV economics and population size. For example, Arizona has access to a very good solar resource, and modeled per-capita installations are high. New York has access to lowerquality solar resource than Arizona, but a similarly sized rooftop PV market develops based on its high relative electricity prices and large population. States that are both populous and have access to very good solar resources, like California, Texas, and Florida, reach the highest levels of simulated PV demand.

\section{Cumulative Rooftop PV Capacity}
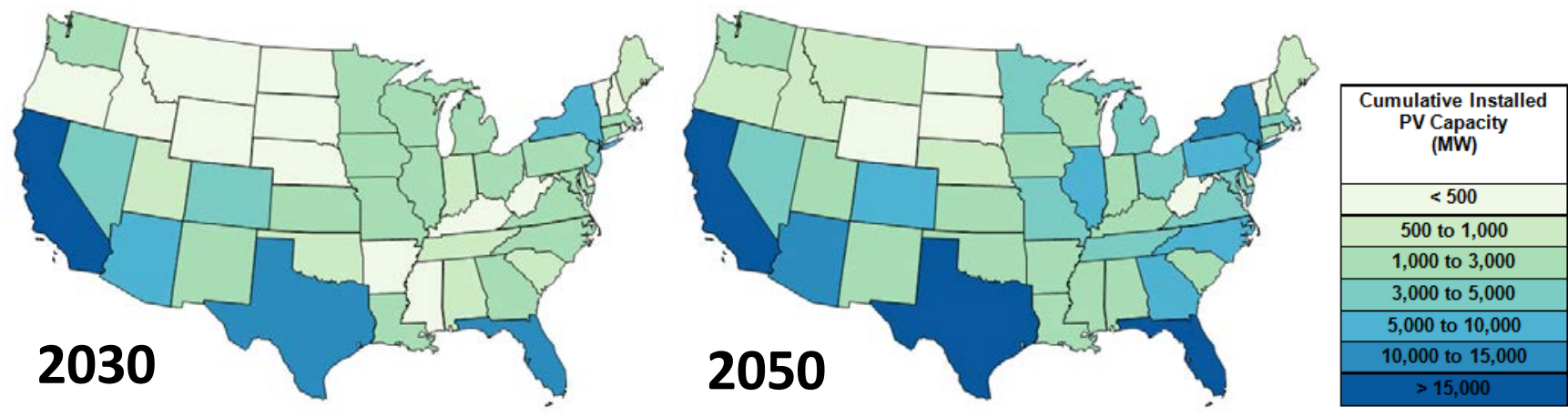

Figure 6. Cumulative rooftop PV capacity for the SunShot scenario 
The electricity generated by rooftop PV capacity is based on the location and orientation of modeled PV projects. In the SunShot scenario, the $121 \mathrm{GW}$ of PV capacity deployed by 2030 generates $164 \mathrm{TWh} / \mathrm{yr}$ of PV electricity (15.5\% capacity factor $\left.{ }^{9}\right)$, which represents about $3.5 \%$ of projected U.S. electricity demand. By 2050, rooftop PV capacity increases to $240 \mathrm{GW}$ and generates about $318 \mathrm{TWh} / \mathrm{yr}(15.1 \%$ capacity factor), or about $5.9 \%$ of projected U.S. electricity demand. Utility-scale PV and CSP resources were also modeled in the SunShot Vision Study (DOE 2012), and total solar generation reached $642 \mathrm{TWh} / \mathrm{yr}$ by 2030 (13.8\% of U.S. electricity demand) and $1,448 \mathrm{TWh} / \mathrm{yr}$ by 2050 (26.9\% of demand). Simulated rooftop PV markets contributed about $25 \%$ of the total solar electricity in 2030 and $22 \%$ of solar electricity in 2050 .

\footnotetext{
${ }^{9} \mathrm{PV}$ capacity factors represent the average amount of electrical energy (alternating current) generated by a given amount of PV capacity (direct current nameplate capacity) over a period of time. For example, if a $5-\mathrm{kW}_{\mathrm{DC}}$ residential PV system has a $15 \%$ capacity factor, it would annually generate: $5 \mathrm{~kW}_{\mathrm{DC}} * 0.15 \mathrm{~kW}_{\mathrm{AC}} / \mathrm{kW}_{\mathrm{DC}} * 8,760 \mathrm{~h} / \mathrm{yr}$ $=6,570 \mathrm{kWh}_{\mathrm{AC}} / \mathrm{yr}$.
} 


\section{Sensitivity of Rooftop PV Penetration to Varying Market Parameters}

While PV demand is driven by several market assumptions (Tables 2 and 3), we focus here on exploring the impact of four key market parameters: (1) PV down payment fractions; (2) the value of PV-generated electricity; (3) retail electricity rate escalations; and (4) different parameterizations of aggregate customer behavior. Table 4 summarizes the SunShot scenario assumptions for each parameter and the ranges explored in the sensitivity analysis.

Table 4. Parameters Explored in the Sensitivity Analysis

\begin{tabular}{|c|c|c|c|}
\hline Model Parameter & Reference & Low Range & High Range \\
\hline $\begin{array}{l}\text { Down Payment } \\
\text { Fraction }\end{array}$ & $\begin{array}{l}20 \% \text { for residential customers } \\
\text { a } \\
40 \% \text { for commercial customers }\end{array}$ & $\begin{array}{l}100 \% \text { (residential } \\
\text { and commercial) }\end{array}$ & $\begin{array}{l}0 \% \text { (residential and } \\
\text { commercial) }\end{array}$ \\
\hline PV Electricity Value ${ }^{b}$ & $\begin{array}{l}90 \% \text { retail rates } / 10 \% \text { natural gas } \\
\quad \text { for residential; } \\
100 \% \text { retail rates for commercial }\end{array}$ & $\begin{array}{l}100 \% \text { natural gas } \\
\text { (residential and } \\
\text { commercial) }\end{array}$ & $\begin{array}{l}100 \% \text { retail rates } \\
\text { (residential and } \\
\text { commercial) }\end{array}$ \\
\hline $\begin{array}{l}\text { Electricity Rate } \\
\text { Escalations }\end{array}$ & EIA 2010 & $0 \%$ (real dollars) & $1 \%$ (real dollars) \\
\hline $\begin{array}{l}\text { Customer Behavior } \\
\text { Parameterizations }\end{array}$ & Paidipati et al. 2008 & EIA 2004 & $\begin{array}{l}\text { R.W. Beck, Inc. } \\
2009\end{array}$ \\
\hline
\end{tabular}

${ }^{\mathrm{a}}$ See Table 3 .

${ }^{\mathrm{b}}$ The valuation of PV-generated electricity is described in Table 2 and in the text below.

Each parameter in Table 4 was chosen to explore the potential impacts of current market trends (innovative financing), uncertain market projections (e.g., future retail electricity rates, rate structures, and net-metering policy), and key model parameterizations (the representation of consumer behavior). PV down payment fractions were chosen from $0 \%$ to $100 \%$ to evaluate the potential impact of different financing strategies. A $0 \%$ down payment fraction was used to explore the possible impacts of innovative financing measures like Property Assessed Clean Energy (PACE) financing (Fuller et al. 2009; NREL 2010) or third-party PV products (NREL 2009; Drury et al. 2012). A 100\% down payment fraction was used to explore the possible impact of customers not financing PV systems, particularly as prices decline toward SunShot targets.

We explore different methods for valuing PV electricity to estimate the impact of possible modifications to customer rate structures, like changing net-metering policies (e.g., VSI/NNEC 2011). PV electricity is frequently valued at retail electricity rates in most states. Retail rates include the cost of several electric sector services, such as electricity transmission and distribution and grid reliability, that are not offset by PV generation. As such, distributed PV customers frequently benefit from cross-subsidies. We explore an upper bound on PV market potential using full retail electricity rates to characterize market demand if PV continues to be valued at retail electricity rates in key U.S. markets. We also explore a lower bound on PV market potential if PV generation is valued at the variable cost of natural gas generation, ${ }^{10}$ which

\footnotetext{
${ }^{10}$ The value of offsetting natural gas generation depends on several factors, including regional gas prices, time- and region-dependent mix of combined cycle and combustion turbine generators, O\&M costs, and other factors. We estimate the average cost of natural gas generation for each state based on fuel and electricity prices from (EIA
} 
is frequently the marginal energy resource during times of peak PV generation. This sensitivity does not characterize the impact of specific new policies or the full range of possible retail rate structures to bound PV penetration levels ${ }^{11}$; instead, it captures the sensitivity of PV demand to one possible range of future PV electricity values.

Future electricity rate escalations (or de-escalations) are impacted by several factors, including future fuel prices, electricity demand, commodity costs, and emissions policies to limit carbon or criterion pollutants. In the SunShot Vision Study, electricity rate projections were based on AEO 2010 (EIA 2010), which showed a state-based average increase of $0.7 \% /$ year (real dollars) for residential customers and $0.5 \% /$ year for commercial customers. Here, we explore the impact of $0 \%$ and $1 \%$ annual escalation rates (real dollars) on future PV deployment.

Lastly, individual-level consumer behavior is complex and dynamic, and it is challenging to represent with simple parameterizations. Previous studies have developed different representations of aggregate customer adoption behavior (EIA 2004; Paidipati et al. 2008; R.W. Beck, Inc. 2009). While none of these parameterizations are detailed enough to characterize individual-level customer behavior (e.g., Rogers 2003; Faiers and Neame 2006; Wilson and Dowlatabadi 2007; Rai and Robinson 2012), they aim to represent aggregate adoption trends. Here, we explore the impact of using two different parameterizations of PV adoption (EIA 2004; R.W. Beck, Inc. 2009) in addition to the reference relationship (Paidipati et al. 2008) used in the SunShot Vision Study. We do not anticipate that these different representations of aggregate behavior will bound the impacts of complex diffusion dynamics (Bollinger and Gillingham 2012; Drury et al. 2012; Rai and Robinson 2012); rather, we explore the sensitivity of model results to different aggregate adoption assumptions.

Figure 7 and Table 5 show modeled residential, commercial, and total rooftop PV penetration levels for the range of market assumptions described above. The PV penetration levels in the SunShot scenario are shown by bold colored lines in each figure, and the parameter-specific ranges are shown by the shaded area. Each sensitivity varies one parameter in isolation, and all other market variables are represented by the reference SunShot values (Table 4). Modeled sensitivities are based on the market representations within the SolarDS model ${ }^{12}$ and are intended to highlight possible market trends.

2009) along with natural gas combined cycle and combustion turbine characteristics from (Black \& Veatch 2012), and use these to scale the regional rate distributions calculated from (EIA 2007). This methodology produces variable natural gas generation costs ranging from $\$ 35-\$ 75 / \mathrm{MWh}$, based on regional differences in natural gas prices, and a state-based mean of $\$ 61 / \mathrm{MWh}$. This variable cost is consistent with natural gas prices ranging from \$4-\$6/MMBTU with PV offsetting 66\%-80\% combined cycle generation and 20\%-33\% combustion turbine generation, after accounting for operations and maintenance costs and transmission and distribution line losses (Black \& Veatch 2012). We do not project future natural gas prices since these are inherently uncertain; rather, we assume that the variable value of offsetting natural gas generation remains fixed (real dollars) for the study duration. ${ }^{11}$ Each sensitivity is calculated in isolation, so it is unlikely that individual sensitivities will bound possible PV revenue streams. Also, the scenario analysis does not explore potential fuel price variations or other factors that could influence the value of PV electricity.

${ }^{12}$ For example, PV economic returns are characterized by payback times in SolarDS, which are sensitive to assumed down payment fractions (Drury et al. 2011). PV deployment levels could show different sensitivities to down payment fractions and other market parameters, if different economic performance metrics were used to characterize PV investment returns (Drury et al. 2011). 
Residential

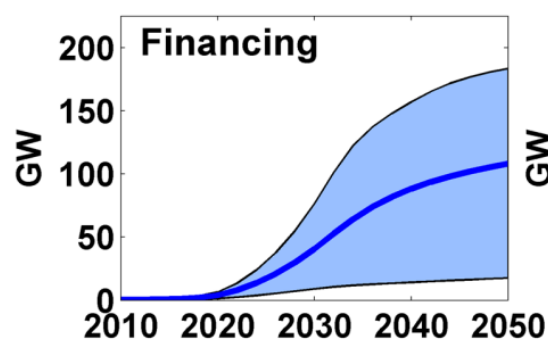

Commercial

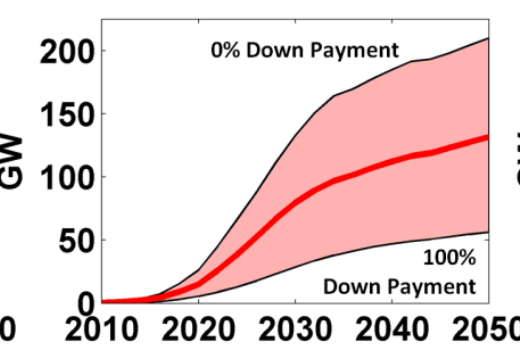

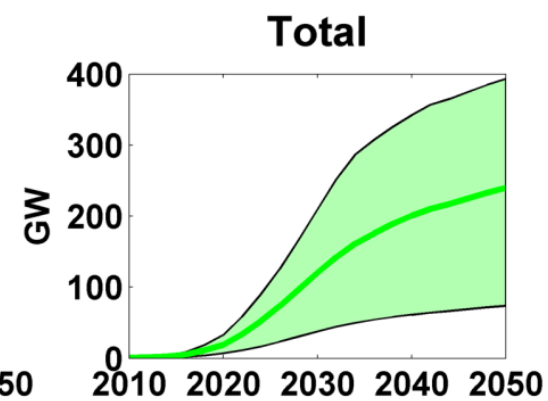
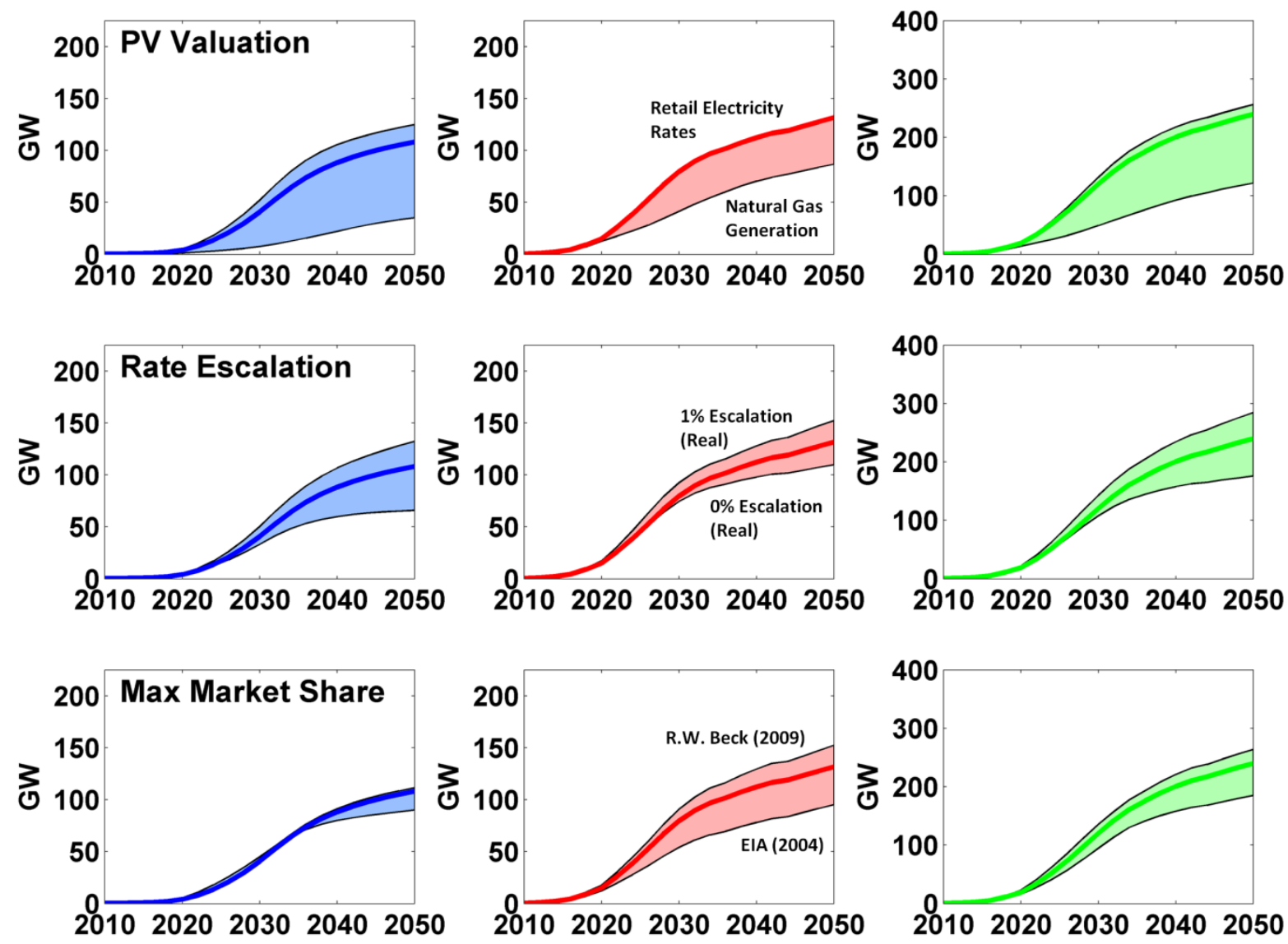

Figure 7. Modeled rooftop PV demand for the SunShot PV price assumptions (Table 1) and a range of non-price market parameters (Table 4)

Note: SunShot markets are shown by bold colored lines, and the lighter color shades show market penetrations for the range in market parameters.

Figure 7 shows that simulated PV markets are most sensitive to the range of down payment fractions explored in this analysis ( $0 \%$ versus $100 \%$ down payment), followed by the range in PV valuation assumptions (retail electricity rates versus the value of offsetting natural gas generation). Simulated deployment is less sensitive to the range in retail electricity rate escalations explored in this analysis ( $0 \%$ versus $1 \%$ annual escalation rates in real dollars) and the different parameterizations of customer behavior (R.W. Beck, Inc. 2009 versus EIA 2004). 
Table 5. Rooftop PV Capacity (GW $\mathrm{GC}_{\mathrm{DC}}$ ) for a Range of Non-Price Market Parameters

\begin{tabular}{|c|c|c|c|c|}
\hline Total PV & $\mathbf{2 0 2 0}$ & $\mathbf{2 0 3 0}$ & $\mathbf{2 0 4 0}$ & $\mathbf{2 0 5 0}$ \\
\hline Reference & $\mathbf{1 9}$ & $\mathbf{1 2 1}$ & $\mathbf{2 0 1}$ & $\mathbf{2 4 0}$ \\
\hline Financing & $7-33$ & $38-209$ & $61-342$ & $74-393$ \\
\hline PV Valuation & $14-20$ & $49-132$ & $93-218$ & $122-256$ \\
\hline Rate Escalation & $19-22$ & $108-143$ & $158-234$ & $176-285$ \\
\hline $\begin{array}{c}\text { Maximum } \\
\text { Market Share }\end{array}$ & $16-23$ & $95-136$ & $158-221$ & $186-264$ \\
\hline Residential PV & $\mathbf{2 0 2 0}$ & $\mathbf{2 0 3 0}$ & $\mathbf{2 0 4 0}$ & $\mathbf{2 0 5 0}$ \\
\hline Reference & $\mathbf{4}$ & $\mathbf{4 1}$ & $\mathbf{8 9}$ & $\mathbf{1 0 8}$ \\
\hline Financing & $2-6$ & $9-76$ & $14-157$ & $18-183$ \\
\hline PV Valuation & $1-5$ & $8-52$ & $22-106$ & $35-125$ \\
\hline Rate Escalation & $4-5$ & $33-50$ & $60-107$ & $66-132$ \\
\hline $\begin{array}{c}\text { Maximum } \\
\text { Market Share }\end{array}$ & $4-5$ & $41-45$ & $80-91$ & $90-111$ \\
\hline Commercial PV & $\mathbf{2 0 2 0}$ & $\mathbf{2 0 3 0}$ & $\mathbf{2 0 4 0}$ & $\mathbf{2 0 5 0}$ \\
\hline $\begin{array}{c}\text { Reference } \\
\text { Financing }\end{array}$ & $\mathbf{1 5}$ & $\mathbf{8 0}$ & $\mathbf{1 1 2}$ & $\mathbf{1 3 2}$ \\
\hline $\begin{array}{c}\text { PV Valuation } \\
\text { Rate Escalation }\end{array}$ & $13-15$ & $\mathbf{2 9 - 1 3 3}$ & $47-185$ & $56-210$ \\
\hline $\begin{array}{c}\text { Maximum } \\
\text { Market Share }\end{array}$ & $12-17$ & $\mathbf{4 2 - 8 0}$ & $71-112$ & $87-132$ \\
\hline & & $54-91$ & $98-128$ & $110-152$ \\
\hline
\end{tabular}

PV deployment rates are particularly sensitive to down payment fractions, in part, because they strongly influence the economic performance metrics used in SolarDS (Drury et al. 2011). Modeled sensitivities to down payment fractions are higher for residential markets $(-81 \%$ to $+85 \%$ in $2030 ;-83 \%$ to $+69 \%$ in 2050$)$ than commercial markets $(-64 \%$ to $+66 \%$ in $2030 ;-58 \%$ to $+59 \%$ in 2050) and show a similar impact on mid-term (2030) and long-term (2050) PV growth. Model sensitivities suggest that access to (or lack of access to) innovative financing products could significantly impact residential and commercial PV demand.

Modeled sensitivities to the PV valuation parameters show significantly more downside market impact $(-60 \%$ in $2030 ;-49 \%$ in 2050$)$ than upside potential $(+9 \%$ in $2030 ;+7 \%$ in 2050$)$. This is because we assumed that $100 \%$ of commercial PV electricity and $90 \%$ of residential PV electricity is valued at retail rates in the SunShot scenario, ${ }^{13}$ whereas the lower bound values PV electricity at the variable cost of natural gas generation. The model results suggest that modifying net-metering policies or retail rate structures in such a way that the value of PV electricity approaches that of natural gas could significantly decrease both commercial PV demand (-48\% in 2030; $-34 \%$ in 2050) and residential PV demand (-80\% in $2030 ;-68 \%$ in 2050). The smaller impact on modeled commercial markets is likely driven by several factors, including lower commercial PV prices, commercial asset depreciation, and the use of IRR-based payback times for commercial customers as discussed above and in Drury et al. (2011).

\footnotetext{
${ }^{13}$ We assumed that commercial customers would actively size PV installations so that all PV electricity would offset local electricity demand and because a significant fraction of commercial customers are modeled as being on demand-based rates (Denholm et al. 2009).
} 
Modeled PV demand is less sensitive to the range of rate escalations (-11\% to $+18 \%$ in $2030 ;-19 \%$ to $+27 \%$ in 2050$)$ and different parameterizations of customer behavior $(-12 \%$ to $+21 \%$ in $2030 ;-10 \%$ to $+23 \%$ in 2050 ). The impact of different rate escalations increases over time as escalation rates compound, and rate escalations have a larger impact on residential PV demand $(-22 \%$ to $+20 \%$ by $2030 ;-22 \%$ to $+39 \%$ by 2050$)$ than commercial demand $(-16 \%$ to $+6 \%$ in $2030 ;-15 \%$ to $+17 \%$ in 2050 ). Conversely, different customer behavior parameterizations have a larger impact on commercial PV demand (-14\% to $+33 \%$ by 2030 ; $15 \%$ to $+28 \%$ by 2050 ) than residential demand (-10\% to $0 \%$ in $2030 ;-3 \%$ to $+17 \%$ in 2050$)$.

One notable modeling result is that robust rooftop PV markets develop in all scenarios where SunShot PV prices are reached. Even the lowest levels of simulated rooftop PV demand, seen in the $100 \%$ down payment scenario, reach $38 \mathrm{GW}$ by 2030 and $74 \mathrm{GW}$ by 2050 . While this represents a 69\% decline in PV demand from the SunShot scenario projections in 2030 and 2050, this still represents robust growth in U.S. rooftop market demand, up from about $3.9 \mathrm{GW}$ of rooftop PV capacity installed by the end of Q3 2012 (SEIA-GTM 2012).

The range in PV demand illustrates both the sensitivity of PV markets to evolving solar policies and business models and the scale of uncertainties inherent to simulating market projections. One challenge in interpreting the modeled range in demand is estimating the relative likelihood of realizing the upper or lower bounds for each parameter and the possible combinations of parameters. For example, assuming a 100\% down payment fraction (no financing) has a large impact on modeled PV markets, but it is unlikely that the entire rooftop PV market will stop financing systems. However, retail electricity rate escalations could reasonably reach $0 \%$ or $1 \%$ annually (real dollars), making the upper and lower bounds of this scenario much more likely by comparison. Combining both the sensitivity of rooftop PV markets to each parameter and estimating the likelihood of realizing values within the ranges for each parameter will be the focus of subsequent analysis, both for rooftop and wholesale PV markets. 


\section{Sensitivity of Rooftop Markets to PV Prices and Non-Price Parameters}

The SunShot Vision Study assumed a fixed price trajectory for residential and commercial rooftop PV systems (Table 1). In this section, we explore the combination of a range of PV prices and non-price market parameters on PV demand. This is used to identify potential PV price thresholds that could entice wide-scale PV adoption and how these price thresholds vary for a range of market parameters.

Figure 8 illustrates seven PV price projections that were explored in addition to the SunShot targets. All prices are assumed to decline linearly from 2010 system prices to reach a final price target ranging from $\$ 1 / \mathrm{W}$ to $\$ 4 / \mathrm{W}$ by 2020 in $\$ 0.50 / \mathrm{W}$ increments, and prices are assumed to stay fixed in real dollars from 2020-2050 (as in the SunShot scenario). For clarity, only the residential price projections are shown in Figure 8; commercial prices are assumed to be lower than residential prices before 2020 based on their lower 2010 starting price and identical to residential prices after 2020. Six scenarios represent incomplete realizations of the SunShot price goals $(\$ 1.50 / \mathrm{W}$ to $\$ 4.00 / \mathrm{W}$ by 2020$)$, and one scenario explores the impact of reaching additional price improvements $(\$ 1.00 / \mathrm{W})$. We simulated PV market demand for each of the seven price projections shown in Figure 8, for the reference SunShot scenario market assumptions, and the four sensitivities listed in Table 4.

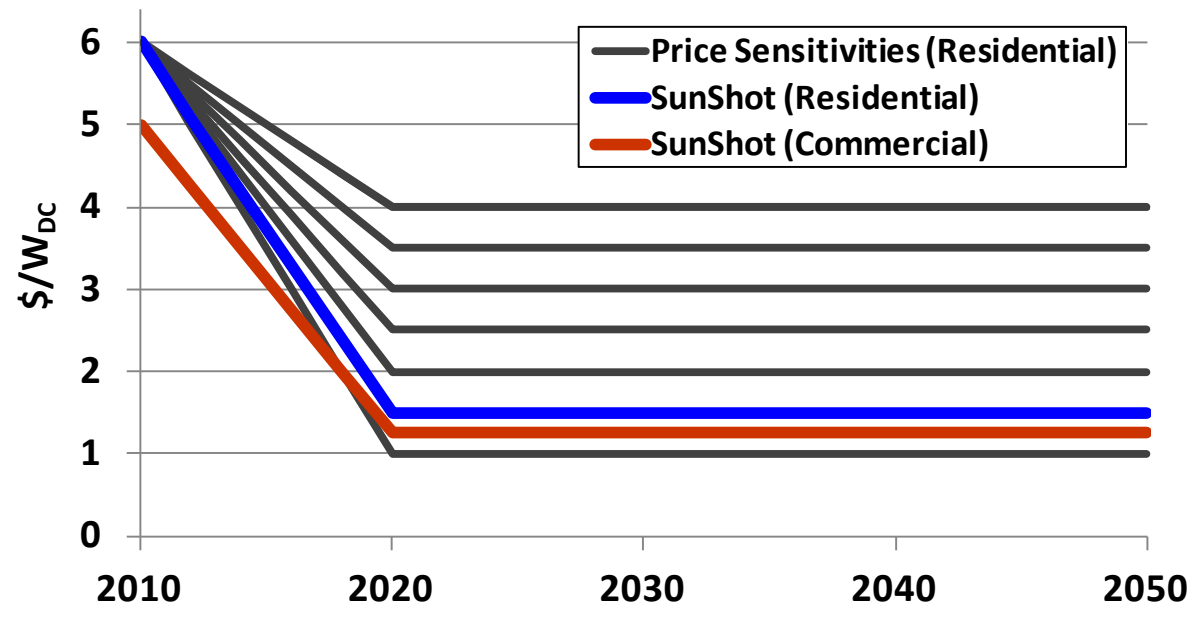

Figure 8. SunShot PV price assumptions for residential and commercial systems and the price sensitivities explored for residential systems. Similar price sensitivities are used for commercial systems with a \$5/W starting price in 2010 and identical 2020-2050 prices.

Figure 9 shows the increase in rooftop PV demand with decreasing PV prices, calculated for 2030 and 2050 markets, using the PV price trajectories from Figure 8 and the reference SunShot assumptions listed in Tables 2 and 3. Simulated residential PV demand is still lower than commercial demand but less so than in the SunShot scenario (Figure 5) because we assume that residential and commercial systems are the same price. Residential demand remains lower than commercial, except for very low PV prices by 2050 , based on commercial access to capital depreciation and the use of IRR-based payback times as discussed in Section 3. The higher modeled residential PV demand in 2050 for $\$ 1 / \mathrm{W}$ PV suggests that commercial markets are beginning to saturate, allowing residential demand to slightly exceed commercial demand. 

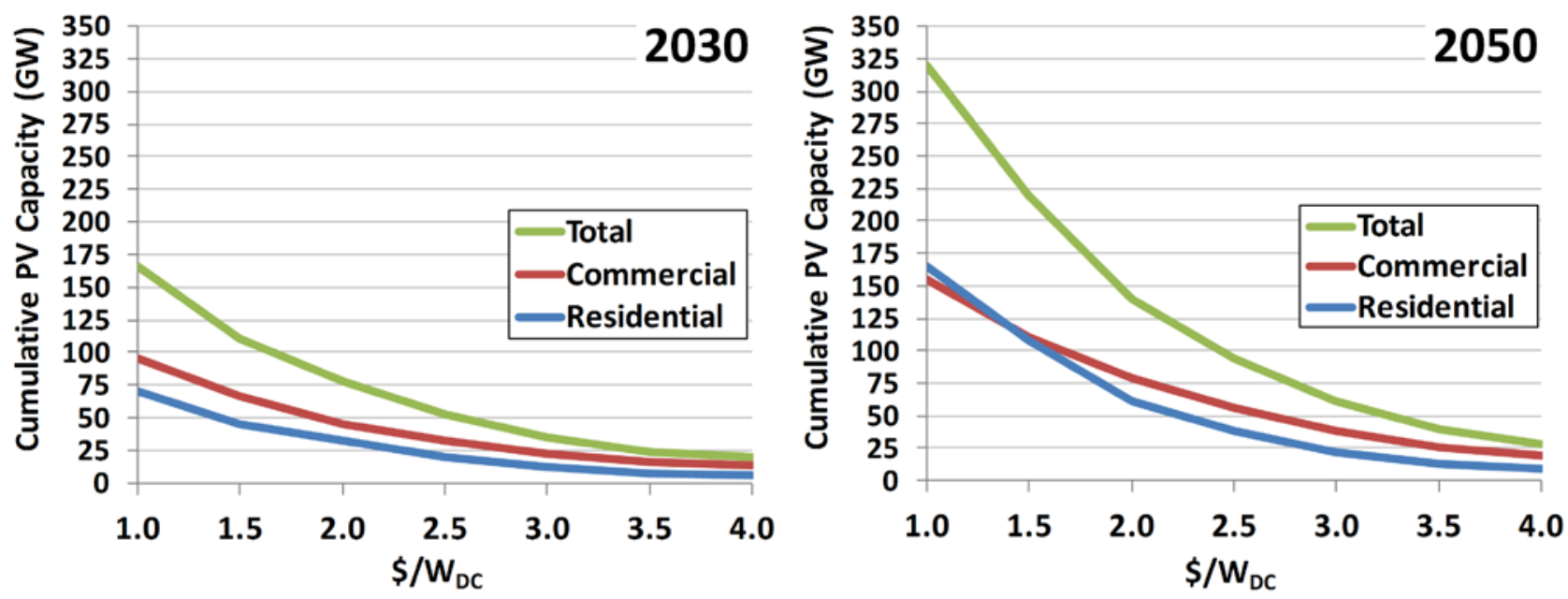

Figure 9. Sensitivity of rooftop PV demand to a range of PV prices for 2030 and 2050

Figure 9 relates the prices that PV systems may need to reach to support various levels of rooftop PV demand based on the SunShot scenario market assumptions. For example, to reach $25 \mathrm{GW}$ of demand by 2030, PV prices may need to fall below $\$ 3.50 / \mathrm{W}$, to reach $50 \mathrm{GW}$ of demand PV prices may need to fall below $\$ 2.50 / \mathrm{W}$, and to reach $100 \mathrm{GW}$ of demand PV prices may need to fall below $\$ 1.60 / \mathrm{W}$. Modeled PV demand increases over time at fixed prices based on the diffusion of PV into its full market potential, characterized by the Bass diffusion parameters assumed in SolarDS.

While the relationships linking PV prices to market demand are non-linear, which leads to larger increases in modeled demand for incremental price reductions at lower PV prices, there are no clear price thresholds that separate marginal PV demand from robust growth. Market projections clearly increase more rapidly for price reductions below $\$ 3 / \mathrm{W}$, but we also find significant modeled PV demand at prices higher than this. For example, \$3/W PV supports $35 \mathrm{GW}$ of modeled PV demand by 2030 and $65 \mathrm{GW}$ by 2050. We do find that modeled residential PV demand increases more rapidly with decreasing prices than commercial demand. For example, $\$ 4 / \mathrm{W}$ PV supports only about $5 \%$ of the residential demand simulated for $\$ 1 / \mathrm{W}$ prices by 2050 (relative to $15 \%$ for commercial), $\$ 3 / \mathrm{W}$ PV supports about $10 \%$ of simulated $\$ 1 / \mathrm{W}$ residential demand ( $25 \%$ for commercial), and $\$ 2 / \mathrm{W}$ PV supports about $35 \%$ of simulated $\$ 1 / \mathrm{W}$ residential demand $(50 \%$ for commercial). This suggests that achieving significant PV price reductions could have a larger impact for stimulating residential rooftop PV demand than commercial demand.

In addition to the sensitivity of rooftop PV market demand to PV systems prices, we also explore how the combination of PV prices and non-price market parameters impact PV demand in Figure 10 (2030 PV demand) and Figure 11 (2050 demand). Both figures show the range of simulated PV deployment as a function of price based on the market parameters listed in Table 4. For example, the upper bound on PV demand in the top row of Figures 10 and 11 (labeled 'Financing') represents simulated PV demand for systems with a $0 \%$ down payment fraction for the full range of PV prices, the lower bound represents a $100 \%$ down payment fractions for the range of prices, and the bold line in the middle of the range represents simulated demand for reference assumptions used in the SunShot Vision Study (Table 3). 

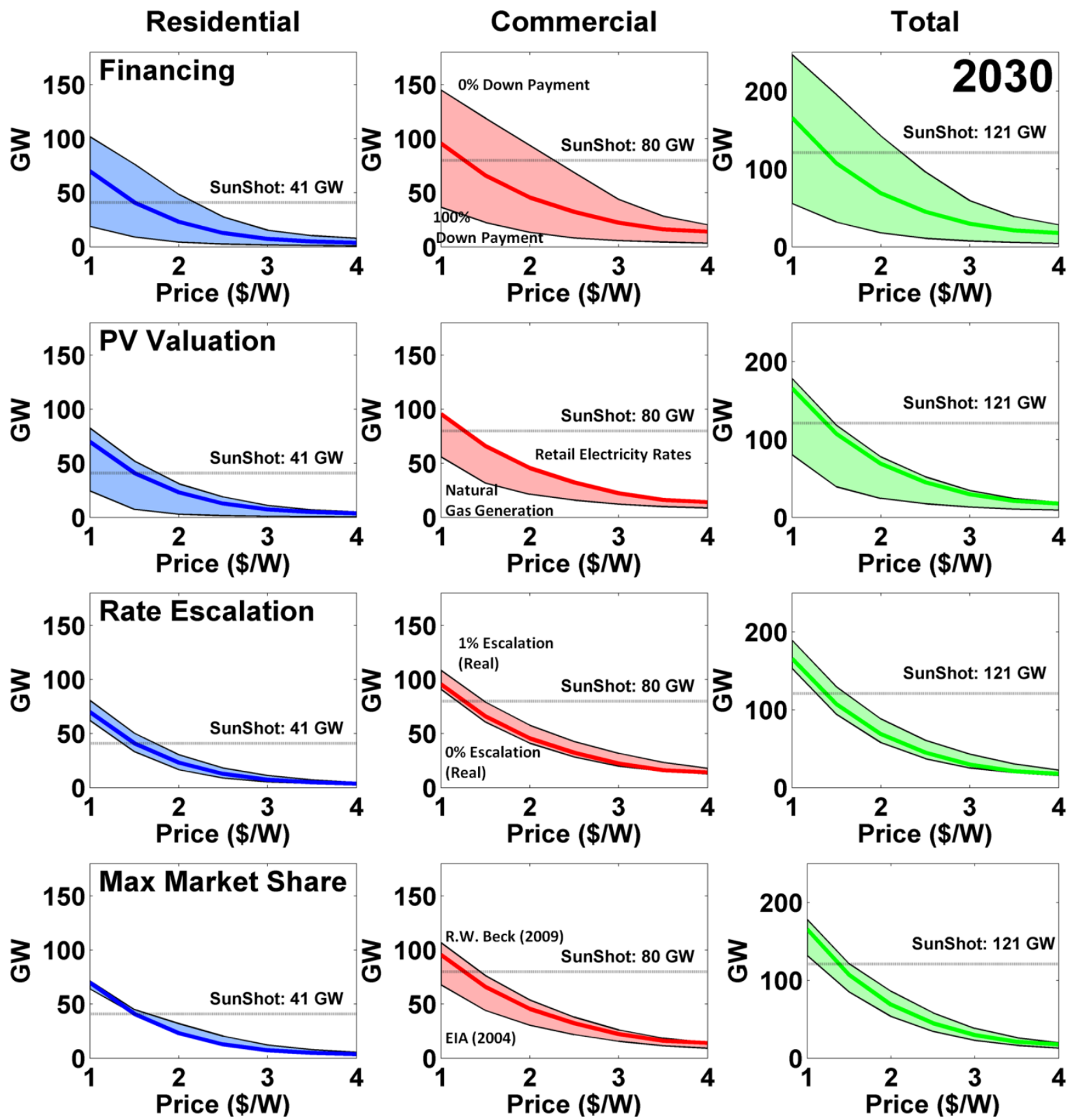

Figure 10. Rooftop PV demand for a range of PV prices and other market assumptions in 2030

Note: SunShot markets are shown by the horizontal grey lines, and market penetrations are shown for the reference assumptions by bold colored lines and for the range in market parameters by lighter color shades.

The vertical extent of the range in PV demand for a fixed PV system price shows the impact of each non-price market parameter and how these impacts vary over a range of system prices. For example, Figures 10 and 11 show that the vertical extent of the PV demand ranges increase significantly with decreasing PV prices, with the exception of residential parameterizations of aggregate customer behavior. Varying market parameters has a larger total impact (GW of demand) at lower PV prices but a similar relative impact (fractional increase or decrease in 
demand) across all prices. Tables 6 and 7 summarize the price trends shown in Figures 10 and 11 .

Table 6. Modeled 2030 Rooftop PV Demand $\left(G_{D C}\right)$ for Several Installed PV System Prices and a Range of Market Assumptions

\begin{tabular}{|c|c|c|c|c|}
\hline \multicolumn{5}{|l|}{2030} \\
\hline Total PV $(\mathbf{G W})^{\mathrm{a}}$ & $\$ 1 / \mathbf{W}_{D C}$ & $\$ 2 / W_{D C}$ & $\$ 3 / \mathbf{W}_{D C}$ & $\$ 4 / W_{D C}$ \\
\hline SunShot & 166 & 69 & 30 & 18 \\
\hline Financing & $56-247$ & $18-142$ & $8-59$ & $5-28$ \\
\hline PV Valuation & $81-178$ & $24-77$ & $13-34$ & $10-19$ \\
\hline Rate Escalation & $153-190$ & $58-88$ & $25-43$ & $16-23$ \\
\hline Maximum Market Share & $132-179$ & $54-86$ & $23-38$ & $13-20$ \\
\hline Residential PV (GW) & $\$ 1 / \mathbf{W}_{\mathrm{DC}}$ & $\$ 2 / W_{D C}$ & $\$ 3 / W_{D C}$ & $\$ 4 / W_{D C}$ \\
\hline SunShot & 70 & 23 & 7 & 4 \\
\hline Financing & 19-102 & $4-48$ & $2-15$ & $1-8$ \\
\hline PV Valuation & $25-83$ & $3-31$ & $1-11$ & $1-5$ \\
\hline Rate Escalation & $62-81$ & $17-30$ & $5-11$ & $3-5$ \\
\hline Maximum Market Share & $64-72$ & $23-32$ & $7-12$ & $4-6$ \\
\hline Commercial PV (GW) & $\$ 1 / W_{D C}$ & $\$ 2 / W_{D C}$ & $\$ 3 / W_{D C}$ & $\$ 4 / W_{D C}$ \\
\hline SunShot & 96 & 46 & 22 & 14 \\
\hline Financing & $37-145$ & $14-94$ & $6-44$ & $4-20$ \\
\hline PV Valuation & $56-96$ & $21-46$ & $12-23$ & $9-14$ \\
\hline Rate Escalation & $91-109$ & $41-58$ & $20-32$ & $13-18$ \\
\hline Maximum Market Share & $68-107$ & $31-54$ & $16-26$ & $9-14$ \\
\hline
\end{tabular}

${ }^{a}$ Total PV demand may differ from the sum of residential and commercial demand due to rounding.

Figure 11 similarly shows the combination of PV prices and non-price market parameters on modeled 2050 PV demand, and Table 7 summarizes these demand levels. Most trends are similar for 2030 and 2050, such as the increasing total impact of varying market parameters (GW of demand) with decreasing system prices, but similar relative impacts (fractional increase in demand) across the range of PV prices. One exception to this is the larger impact of rate escalation assumptions in 2050 based on their compounding effect. We also find that modeled residential demand increases more significantly with decreasing prices than commercial demand, and we find particularly strong growth in residential PV demand for prices below $\$ 2.50 / \mathrm{W}$. 

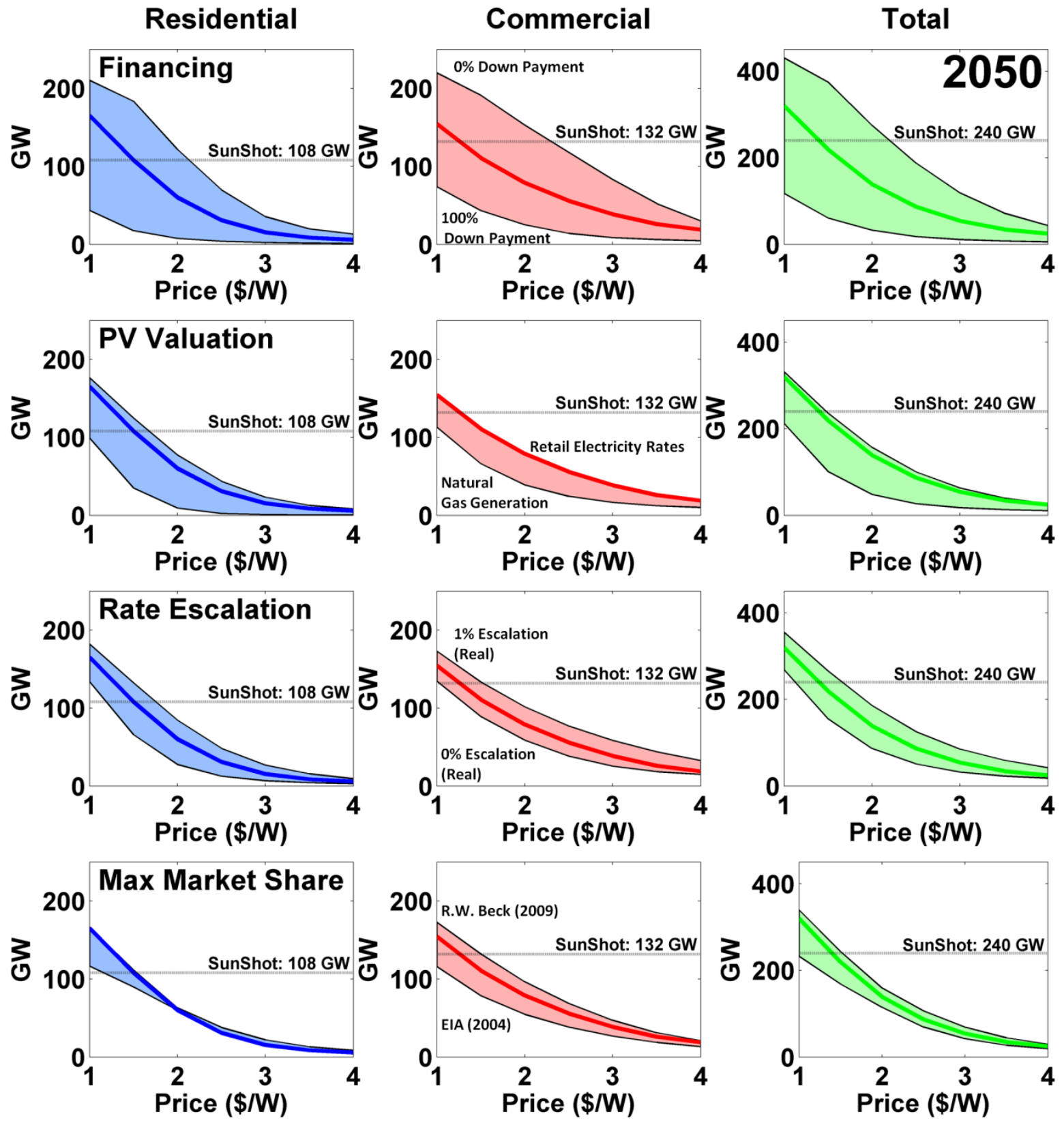

Figure 11. Rooftop PV demand for a range of PV prices and other market assumptions in 2050

Note: SunShot markets are shown by the horizontal grey lines, and market penetrations are shown for the reference assumptions by bold colored lines and for the range in market parameters by lighter color shades. 
Table 7. Modeled 2050 Rooftop PV Demand $\left(G_{D C}\right)$ for Several Installed PV System Prices and a Range of Market Assumptions

\begin{tabular}{|c|c|c|c|c|}
\hline \multicolumn{5}{|l|}{2050} \\
\hline Total PV $(\mathbf{G W})^{a}$ & $\$ 1 / W_{D C}$ & $\$ 2 / W_{D C}$ & $\$ 3 / \mathbf{W}_{D C}$ & $\$ 4 / W_{D C}$ \\
\hline SunShot & 320 & 139 & 54 & 25 \\
\hline Financing & $118-430$ & $33-275$ & $12-119$ & $6-43$ \\
\hline PV Valuation & $212-331$ & $49-157$ & $18-63$ & $11-27$ \\
\hline Rate Escalation & $269-355$ & $87-186$ & $33-86$ & $18-42$ \\
\hline Maximum Market Share & $233-340$ & $115-159$ & $42-69$ & $20-30$ \\
\hline Residential PV (GW) & $\$ 1 / \mathbf{W}_{D C}$ & $\$ 2 / \mathbf{W}_{\mathrm{DC}}$ & $\$ 3 / \mathbf{W}_{D C}$ & $\$ 4 / W_{D C}$ \\
\hline SunShot & 165 & 60 & 15 & 6 \\
\hline Financing & $44-210$ & $8-122$ & $3-36$ & $1-13$ \\
\hline PV Valuation & $99-176$ & $10-77$ & $1-23$ & $1-8$ \\
\hline Rate Escalation & $134-182$ & $28-84$ & $7-27$ & $3-9$ \\
\hline Maximum Market Share & $117-167$ & $60-63$ & $15-22$ & $6-9$ \\
\hline Commercial PV (GW) & $\$ 1 / \mathbf{W}_{\mathrm{DC}}$ & $\$ 2 / W_{D C}$ & $\$ 3 / \mathbf{W}_{D C}$ & $\$ 4 / W_{D C}$ \\
\hline SunShot & 155 & 79 & 39 & 19 \\
\hline Financing & $74-220$ & $25-153$ & $9-83$ & $5-30$ \\
\hline PV Valuation & $113-155$ & $39-80$ & $17-40$ & $10-19$ \\
\hline Rate Escalation & $135-173$ & 59-102 & $26-59$ & $15-33$ \\
\hline Maximum Market Share & $116-173$ & $55-96$ & $27-47$ & $14-21$ \\
\hline
\end{tabular}

a Total PV demand may differ from the sum of residential and commercial demand due to rounding.

In Figures 10 and 11, the horizontal extent of PV demand ranges, for a fixed level of market demand, illustrate the range of installed PV system prices and non-price factors that can combine to produce a given level of simulated demand. For example, $41 \mathrm{GW}$ of residential PV demand was simulated in the SunShot scenario by 2030. This same level of residential PV demand could have been reached at $\$ 2.18 / \mathrm{W}$ rather than $\$ 1.50 / \mathrm{W}$ if all customers had access to $0 \%$ down payment financing. However, if all residential customers stopped financing systems $(100 \%$ down payment fraction), PV prices would have to decrease below $\$ 1 / \mathrm{W}$ to reach $41 \mathrm{GW}$ of modeled market demand. Table 8 shows similar relationships for each non-price market variable.

Table 8. Range in PV Prices (2010 USD/W $\mathrm{DC}_{\mathrm{DC}}$ ) Enabling SunShot Levels of Rooftop PV Market Demand

\begin{tabular}{|c|c|c|c|c|}
\hline Residential (2010 USD/W ${ }_{D C}$ ) & 2020 & 2030 & 2040 & 2050 \\
\hline SunShot & 1.50 & 1.50 & 1.50 & 1.50 \\
\hline Financing & $<1.0-3.70$ & $<1.0-2.18$ & $<1.0-2.09$ & $<1.0-2.13$ \\
\hline PV Valuation & $<1.0-2.31$ & $<1.0-1.76$ & $<1.0-1.70$ & $<1.0-1.68$ \\
\hline Rate Escalation & $1.24-2.09$ & $1.37-1.73$ & $1.28-1.71$ & $1.19-1.75$ \\
\hline Maximum Market Share & $1.47-2.84$ & $1.50-1.65$ & $1.35-1.54$ & $1.16-1.54$ \\
\hline Commercial (2010 USD/W $\left.{ }_{D C}\right)$ & 2020 & 2030 & 2040 & 2050 \\
\hline SunShot & 1.25 & 1.25 & 1.25 & 1.25 \\
\hline Financing & $<1.0-3.26$ & $<1.0-2.27$ & $<1.0-2.26$ & $<1.0-2.30$ \\
\hline PV Valuation & $<1.0-1.65$ & $<1.0-1.27$ & $<1.0-1.27$ & $<1.0-1.26$ \\
\hline Rate Escalation & $1.27^{\mathrm{a}}-1.87$ & $1.18-1.49$ & $1.10-1.48$ & $1.03-1.52$ \\
\hline Maximum Market Share & $<1.0-1.95$ & $<1.0-1.44$ & $<1.0-1.48$ & $<1.0-1.50$ \\
\hline
\end{tabular}

${ }^{a}$ The reference rate escalation assumptions used in the SunShot Vision Study (EIA 2010a) show some regions with rate escalations and others with de-escalations. We find that a $0 \%$ rate escalation assumption (real dollars) for all regions can produce higher commercial PV demand in 2020 than the EIA-based projections. 
Table 8 shows that the range of PV prices producing SunShot levels of modeled deployment are similar for 2030-2050 for all parameters except rate escalations, which compound over time. Larger price ranges are seen in 2020, based on the assumption that PV prices linearly decline from 2010 values to the SunShot price targets by 2020 (Figure 8 ). The 2030-2050 price ranges express the impact of each non-price market parameter relative to the PV prices required to generate similar demand. For example, if commercial rooftop PV prices were at about $\$ 2.25$ $\$ 2.30 / \mathrm{W}$, modeled PV demand could be increased by a similar amount if: (1) PV prices were decreased to $\$ 1.25 / \mathrm{W}$, or (2) customers were given the option to finance PV systems with zero down payment. We find similar trends for other market parameters.

In addition to exploring the impact of reaching PV prices that are higher or lower than SunShot targets by 2020, we also explored the impact of reaching the SunShot price targets after 2020. Figure 12 shows simulated market penetrations for a scenario where SunShot prices are reached in $2030^{14}$ rather than 2020. PV penetrations are shown for the range of model variables by light color shades and for the reference SunShot parameters by bold colors; the reference SunShot PV penetrations are shown by dashed black lines.

${ }^{14} 2010$ to $2030 \mathrm{PV}$ prices are modeled using a linear reduction from installed 2010 system prices to SunShot targets by 2030 . 

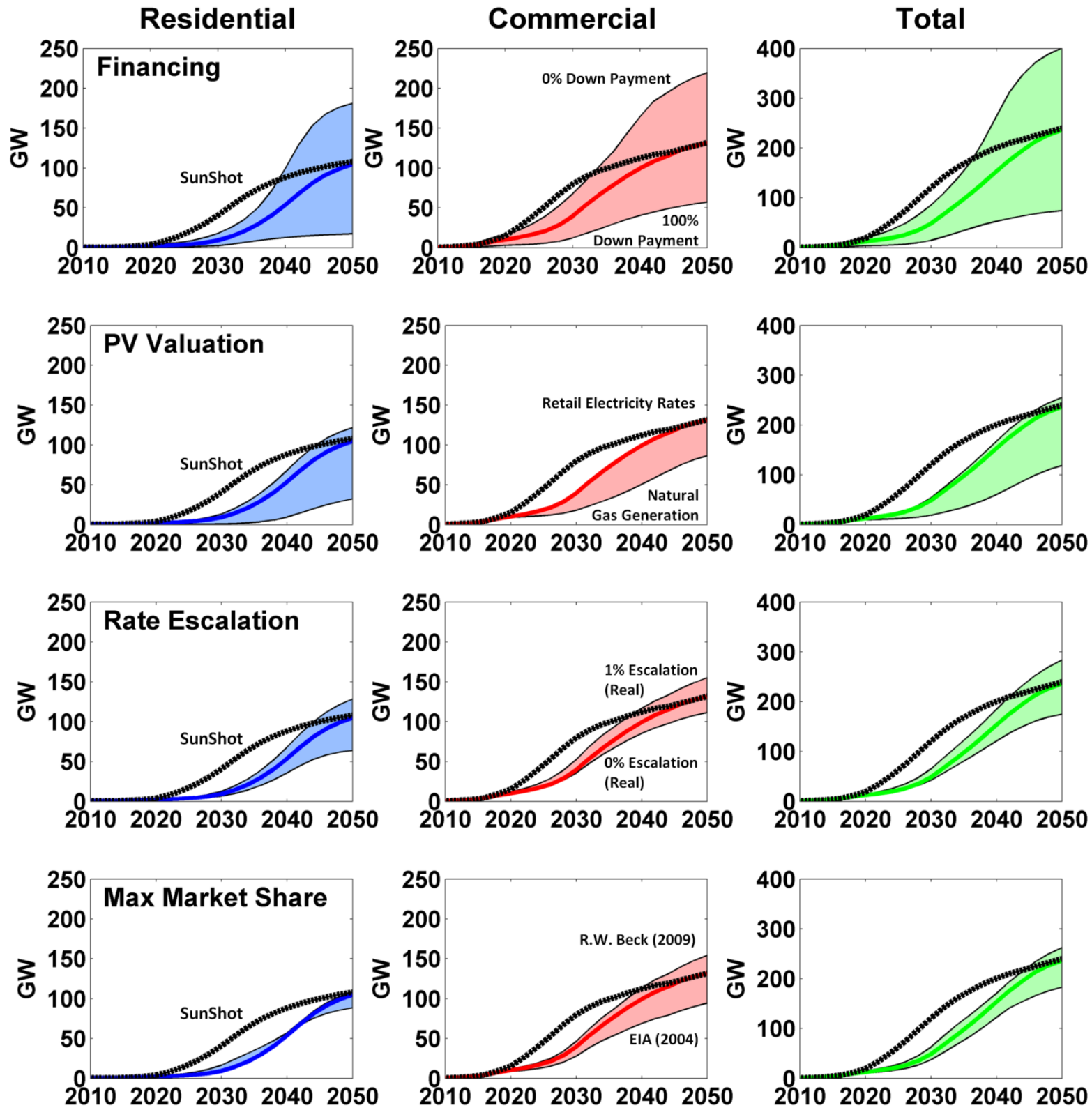

Figure 12. Simulated rooftop PV market demand for SunShot price targets reached in 2030 rather than 2020

Note: Reference SunShot markets are shown by dashed black lines, and market penetrations for the SunShot PV price targets met in 2030 are shown for the reference parameters by bold colored lines and for the range in market parameters by lighter color shades.

Figure 12 shows that delays in reaching the SunShot price targets primarily impact near-term market growth rates but not total PV demand in 2050. Varying non-price market parameters enabled PV markets to reach and exceed SunShot levels by 2050, but the delays in reaching a given level of market demand are at least as long as, and frequently longer than, the assumed delays in reaching SunShot PV prices. This is likely caused by the assumed linear reduction in PV prices to the target levels, at which point strong market penetration would begin to diffuse. 
We ran similar scenarios where SunShot PV price targets are reached in 2040 and 2050, rather than 2020. We similarly find that longer-term PV demand (after 2050) is primarily driven by the magnitude of PV cost reductions, but near- and mid-term PV deployment rates (before 2050) are driven by the pace of PV cost reductions, despite the impact of several non-price market parameters. 


\section{Conclusions}

The SunShot Vision Study (DOE 2012) explored the potential growth of solar markets if solar prices decreased by about $75 \%$ from 2010 to 2020 . The SolarDS model was used to simulate rooftop PV demand based on the SunShot price projections, along with several market assumptions, including future electricity rates and customer access to financing.

In this paper, we find that modeled PV demand is highly sensitive to several non-price market assumptions, particularly PV financing parameters. For example, we find that modifying PV financing terms to change customer down payment fractions to $0 \%$ or $100 \%$ could increase or decrease modeled rooftop PV demand by about 70\%, respectively. However, in addition to finding large sensitivities to market assumptions, we also find that robust PV markets develop in all scenarios explored if the SunShot prices are reached. For example, in the SunShot scenario with the lowest level of PV deployment, modeled rooftop markets reach $38 \mathrm{GW}$ by 2030 and $74 \mathrm{GW}$ by 2050 . This represents robust growth from about $3.9 \mathrm{GW}$ of U.S. rooftop PV capacity installed by the end of Q3 2012 (SEIA/GTM 2012).

We also explored how a range of PV prices (most higher than the SunShot targets) and non-price market parameters combine to produce varying levels of simulated PV demand. We find that non-price market parameters have a similar relative impact (fractional increase or decrease in market demand) for PV prices ranging from $\$ 1 / \mathrm{W}$ to $\$ 4 / \mathrm{W}$ but a much larger absolute impact (increase or decrease in gigawatts deployed) at lower PV prices. We find that PV demand could reach the levels explored in the SunShot Vision Study at prices that are significantly higher than the SunShot targets (up to $\$ 2.18 / \mathrm{W}$ for residential and $\$ 2.27 / \mathrm{W}$ for commercial) when combined with various non-price market assumptions. This suggests additional methods for fostering robust PV market growth even if the SunShot price targets are not completely realized. Lastly, we explored the impact of delays in reaching the SunShot PV price targets, and find that nearand mid-term demand is strongly driven by the pace of PV price improvements, regardless of the impact of non-price market variables, while long-term PV demand is driven by the magnitude of price improvements. 


\section{References}

Audenaert, A.; De Boeck, L.; De Cleyn, S.; Lizin, S.; Adam, J-F. (2010). “An Economic Evaluation of Photovoltaic Grid Connected Systems (PVGCS) in Flanders for Companies: A Generic Model.” Renewable Energy (35); pp. 2674-2682.

Barbose, G.; Darghouth, N.; Wiser, R.; Seel, J. (2011). Tracking the Sun IV: An Historical Summary of the Installed Cost of Photovoltaics in the United States from 1998 to 2010. LBNL5047E. Berkeley, CA: Lawrence Berkeley National Laboratory.

Bass, F.M. (1969). “A New Product Growth for Model Consumer Durables.” Management Science (18); pp. 215-227.

Black \& Veatch. (February 2012). "Cost and Performance Data For Power Generation Technologies." Prepared for the National Renewable Energy Laboratory. Accessed January 14, 2013: http://bv.com/docs/reports-studies/nrel-cost-report.pdf.

Bloomberg New Energy Finance (BNEF). (10 February 2012). "California Versus German Solar Prices: Same Dope, Twice as High.” Solar Research Note. New York, NY: BNEF.

Bollinger, B.; Gillingham, K. (2012). "Peer Effects in the Diffusion of Solar Photovoltaic Panels." Marketing Science.

Darghouth, N.; Barbose, G.; Wiser, R. (2010). The Impact of Rate Design and Net Metering on the Bill Savings from Distributed PV for Residential Customers in California. LBL-3276E. Berkeley, CA: Lawrence Berkeley National Laboratory.

Denholm, P.; Margolis, R. (2008). Supply Curves for Rooftop Solar PV-Generated Electricity for the United States. NREL/TP-6A0-44073. Golden, CO: National Renewable Energy Laboratory.

Denholm, P.; Drury, E.; Margolis, R. (2009). The Solar Deployment Systems (SolarDS) Model: Documentation and Sample Results. NREL/TP-6A2-45832. Golden, CO: National Renewable Energy Laboratory.

U.S. Department of Energy (DOE). (2012). The SunShot Vision Study. DOE/GO-102012-3037. Washington, DC: DOE.

Drury, E.; Denholm, P.; Margolis, R. (2010). Modeling the U.S. Rooftop Photovoltaics Market. Conference Paper for the American Solar Energy Society, Phoenix, Arizona. NREL/CP-6A247823. Golden, CO: National Renewable Energy Laboratory.

Drury, E.; Denholm, P.; Margolis, R. (2011). The Impact of Different Economic Performance Metrics on the Perceived Value of Solar Photovoltaics. NREL/TP-6A20-52197. Golden, CO: National Renewable Energy Laboratory.

Drury, E.; Miller, M.; Macal, C.; Graziano, D.; Heimiller, D.; Ozik, J.; Perry, T. (2012). “The Transformation of Southern California's Residential Photovoltaics Market Through Third-Party Ownership.” Energy Policy (42); pp. 681-690. 
DSIRE. (2012). Accessed August 2012: www.dsireusa.org.

Energy Information Administration (EIA). (2004). The Electricity Market Module of the National Energy Modeling System, Model Documentation Report. DOE/EIA-M068(2004). Washington, DC: EIA.

EIA. (2008a). Commercial Sector Demand Module of the National Energy Modeling System: Model Documentation 2008. DOE/EIA-M066(2008). Washington, DC: EIA.

EIA. (2008b). Model Documentation Report: Residential Sector Demand Module of the National Energy Modeling System. DOE/EIA-M067(2008). Washington, DC: Energy Information Administration.

EIA. (2007). “Form 861.” Accessed August

2009: http://www.eia.gov/cneaf/electricity/page/eia861.html.

EIA. (2009). "State Energy Data System (SEDS) 2009, Primary Energy, Electricity, and Total Energy Price Estimates." Accessed August 2009: http://www.eia.gov/beta/state/seds/.

EIA. (2010a). Annual Energy Outlook 2010 with Projections to 2035. DOE/EIA-0383(2010). Washington, DC: U.S. Department of Energy.

EIA. (2010b). Assumptions to the Annual Energy Outlook 2010. DOE/EIA-0554(2010). Washington, DC: U.S. Department of Energy.

Eurek, K.; Denholm, P.; Margolis, R.; Mowers, M. (2013). Sensitivity of Utility-Scale Solar Deployment Projections in the SunShot Vision Study to Market and Performance Assumptions. NREL/TP-6A20-55836, Golden, CO: National Renewable Energy Laboratory.

Faiers, A.; Neame, C. (2006). "Consumer Attitudes Toward Domestic Solar Power Systems." Energy Policy (34); 1797-1806.

Fuller, M.C.; Portis, S.C.; Kammen, D.M. (7 January 2009). "Toward a Low-Carbon Economy: Municipal Financing for Energy Efficiency and Solar Power." Environment - Science and Policy for Sustainable Development.

Kastovich, J.C.; Lawrence, R.R.; Hoffmann, R.R.; Pavlak, C. (1982). Advanced Electric Heat Pump Market and Business Analysis. ORNL/Sub/79-2471/1, prepared under subcontract to ORNL by Westinghouse Electric Corp. Oak Ridge, TN: Oak Ridge National Laboratory.

Marion, B.; Anderberg, M.; Gray-Hann, P. (2005). Recent Revisions to PVWATTS. NREL/CP520-38975. Golden, CO: National Renewable Energy Laboratory.

National Renewable Energy Laboratory (NREL). (2007). National Solar Radiation Database 1991-2005 Update: User's Manual. NREL/TP-581-41364. Golden, CO: National Renewable Energy Laboratory. 
NREL. (2009). Solar Leasing for Residential Photovoltaic Systems. NREL/FS-6A2-43572. Accessed January 2012: http://www.nrel.gov/docs/fy09osti/43572.pdf.

NREL. (2010). "Property-Assessed Clean Energy (PACE) Financing of Renewables and Efficiency.” NREL/BR-6A2-47097. Accessed January

2012: http://www.nrel.gov/docs/fy10osti/47097.pdf.

Paidipati, J.; Frantzis, L.; Sawyer, H.; Kurrash, A. (2008). Rooftop Photovoltaics Market Penetration Scenarios. NREL/SR-581-42306. Burlington, MA: Navigant Consulting, Inc.

R.W. Beck, Inc. (2009). Distributed Renewable Energy Operating Impacts and Valuation Study. Prepared for Arizona Public Service by R.W. Beck, Inc.

Rai, V.; Robinson, S. (Working paper). "On Information Channels and Peer Effects in the Adoption of Residential Solar PV.”

Rai, V.; Sigrin, B. (2012). Economics of Individual Decision-Making: Buy vs. Lease Differences in the Adoption of Residential Solar. $31^{\text {st }}$ USAEE/IAEE North America Conference, November 4-7, Austin, TX.

Rogers, E. (2003). Diffusion of Innovations. Fifth Edition, New York, NY: Free Press; 551 pp.

Solar Energy Industries Association and Greentech Media Research (SEIA-GTM). (2012). U.S. Solar Market Insight, $3^{\text {rd }}$ Quarter 2012. Accessed September

2012: http://www.greentechmedia.com/research/solarinsight.

Vote Solar Initiative and Network for New Energy Choices (VSI/NNEC). (2011). Freeing the Grid: Best Practices in State Net Metering Policies and Interconnection Procedures. Accessed April 2012: http://freeingthegrid.org/wp-content/uploads/2012/07/FreeingTheGrid2011.pdf.

Wilson, C.; Dowlatabadi, H. (2007). "Models of Decision Making and Residential Energy Use." Annual Review of Environment and Resources (32); pp. 169-203. 